\title{
The Evolution of Top Incomes in an Egalitarian Society: Sweden, 1903-2004*
}

\author{
Jesper Roine* \\ Daniel Waldenström ${ }^{\dagger}$ \\ SSE/EFI Working Paper Series in Economics and Finance No. 625
}

April 6, 2006

\begin{abstract}
:
This study presents new homogenous series of top income shares in Sweden over the period 1903 to 2004. We find that, starting from higher levels of inequality than in other Western countries, the income share of the Swedish top decile drops sharply over the first eighty years of the century. The fall is almost entirely due to a dramatic drop in the top percentile, while the lower half of the top decile experiences virtually no change over this period. Most of the decrease takes place before the expansion of the welfare state, in fact, by 1950 Swedish top income shares were already lower than in other countries. In the past decades the Swedish top income shares developed very differently depending on whether capital gains are included or not. Including them, Sweden's experience resembles that in the U.S. and the U.K. with sharp increases in top incomes, whereas excluding them Sweden looks more like the Continental European countries where top income shares have remained relatively constant. A possible interpretation of our results is that Sweden over the past 20 years has become a country where it is more important make the right investments than to have a high salary to become rich.
\end{abstract}

Keywords: Income inequality, Income distribution, Wealth distribution, Top incomes, Welfare State, Sweden, Taxation, Capital gains.

JEL: D31, H2, J3, N3

\footnotetext{
${ }^{*}$ We are grateful for valuable comments from seminar participants at the Stockholm University (Department of Economics and SOFI), Uppsala University and the European Historical Economics Society Annual Conference 2005. Also special thanks to Anders Björklund for valuable support at several stages in this project.

* Department of Economics, Stockholm School of Economics, P.O. Box 6501, SE-11383 Stockholm, Ph: +46-87369000, E-mail: Jesper.Roine@hhs.se

${ }^{+}$The Research Institute of Industrial Economics, Box 55665, SE-102 15 Stockholm, Sweden, Ph: +46-86654500, E-mail: Daniel.Waldenstrom@iui.se
} 


\section{Introduction}

The evolution of income inequality across different economic systems has received enormous attention. A key issue in the literature has been the possible trade-offs between egalitarian ambitions and incentive effects. It is not surprising therefore that Sweden, allegedly the most extensive welfare state, has been the object of a very large number of studies concerning income distribution. The achievements of the Swedish welfare state are well known. ${ }^{1}$ However, due to the lack of available micro data sets, most recent studies on income distribution have not gone further back than to $1967 .^{2}$ This means that even though we can document achievements of the welfare state over the past decades, we can not really put these in historical perspective. We do not know to what extent the equal distribution of income in Sweden is mainly the outcome of the growth of the welfare state, or if Sweden perhaps has a history of being an egalitarian society.

The lack of homogenous, good quality long run series of income inequality has been a general shortcoming until recently when, following the work by Piketty (2001, 2003), Piketty and Saez (2003), and Atkinson (2004) a number of studies for various countries have constructed long run series of income concentration using a common methodology. ${ }^{3}$ Extending the classic studies by Kuznets $(1953,1955)$ series on top income shares have been calculated using historical tax statistics. These studies have given a number of important new insights into the long run development of income inequality and also found common developments across groups of countries. In particular, while most Western countries experience dramatic drops in top income shares over the first half of the twentieth century, there seems to be important dif-

\footnotetext{
${ }^{1}$ See Lindbeck (1997) for an overview; Atkinson, Rainwater and Smeeding (1995), and Gottshalk and Smeeding (1997) for Swedish income distribution in international perspective; and, e.g. Björklund and Freeman (2006) for a recent overview of income equalization in Sweden.

${ }^{2}$ An exception is Björklund and Palme (2000) who study the Swedish income distribution on decile level during four points in time between 1951 and 1973. Most studies that have analyzed the historical Swedish income distribution of Sweden have looked at shorter sub-periods, using different methodologies and data sources ruling out the construction of homogenous long-run inequality series. Examples include; Spånt (1979) who studied mainly Census data for the period 1920-1976, as did Lydall (1968) for the period 1920-1960; Gustafsson and Johansson (2003) who study tax returns for five separate years during 1925-1958, but only for people living in the City of Gothenburg; Söderberg (1991) who study salaries in various sectors between 1870 and 1950; Lindstrand (1949) study the period 1935-1947 and Quensel (1944) the period 1930-1941, both using tax return data, etc. Bentzel's (1953) study of the period 1930-1948 is closest to ours in methodology. See Roine and Waldenström (2006) for a more complete listing.

${ }^{3}$ Other recent studies include Australia (Atkinson and Leigh, 2006), Canada (Saez and Veall, 2005), Germany (Dell, 2005), Ireland (Nolan, 2005), Japan (Moriguchi and Saez, 2005), the Netherlands (Atkinson and Salverda, 2005), New Zealand (Atkinson and Leigh, 2005), Spain (Alvaredo and Saez 2005) and Switzerland (Dell, Piketty and Saez, 2006). Lindert (2000) and Morrison (2000) provide surveys of previous work.
} 
ferences between Anglo-Saxon countries and continental European countries over the past 30 years (see, e.g., Piketty and Saez, 2006).

This paper makes two main contributions. First, it sheds new light on the evolution of income inequality in Sweden over the twentieth century. Using the methodology developed in Piketty (2001), we provide new homogenous series on top income shares in Sweden, starting at the time of the introduction of the modern tax system in 1902 until today. In 1902 Sweden was still in a phase of industrialization, had not yet extended the franchise to all male citizens, and was still half a century away from the expansion of the Welfare State. Our series, hence, allows us to study changes in income concentration over a period during which Swedish society has undergone major structural change. Our series also allow us to put more recent developments in historical perspective. Furthermore, the fact that we can decompose income shares with respect to the source of income, as well as study smaller fractiles within the top of the distribution (from the top 10 percent up to the top 0.01 percent), makes it possible for us to discriminate between the possible economic mechanisms that could explain our findings. ${ }^{4} \mathrm{We}$ also study changes in wealth concentration and in particular wealth distribution by income class. Second, our study is the first in the recent literature on top income and wealth inequality to study one of the extremes among what Esping-Andersen (1990) denotes "the different worlds of welfare capitalism", namely the social democratic welfare state. ${ }^{5}$ As mentioned above, previous studies have given numerous new insights to changes in income concentration and in particular noted common developments for Anglo-Saxon countries, on the one hand, and continental European countries, on the other. We will compare our series for Sweden to comparable data for other countries and as we will show, Sweden is indeed different from both these groups, although not entirely in ways which may have been expected.

A number of broad facts stand out from our series. Over the first eighty years of the twentieth century top income shares in Sweden decreased. Most of this decrease happened during the

\footnotetext{
${ }^{4}$ Previous work on income inequality in Sweden has mainly focused on issues where overall distribution measures (such as declile ratios or the Gini coefficient) are most relevant and therefore not been concerned with details of the composition and distribution within the top share. However, the top decile is a very heterogeneous group and theories attempting to explain changes in top income shares may be very different if they focus on, for example, high wages rather than capital income. It is therefore important to know details about top incomes to be able to evaluate different theories.

${ }^{5}$ In his distinction between "The Three Worlds of Welfare Capitalism", Esping-Andersen (1990) identifies three different types of welfare states; "liberal welfare states" (e.g. the U.S. and the U.K.), the "corporatistconservative welfare states" (e.g. France, Germany, Italy) and the "social democratic welfare states". A similar distinction is often made between an Anglo-Saxon, a Continental European, and a Scandinavian group of countries; see e.g. Lindbeck (2006).
} 
first half of the century, that is, before the expansion of the Welfare State, and most of it was due to large falls in the income share of the top percentile (P99-100). By contrast, the income share going to the lower half of the top decile (P90-P95), which consists mainly of wages, has been remarkably stable over the entire period. Between 1903 and 2004 this share has fluctuated between 9 and 11 percent, while the top percentile has changed by a factor of 4 . This suggests that decomposing the top decile into smaller fractions is crucial for understanding the development. In terms of composition, most of the early decrease seems to have been driven by falls in capital income, but after around the mid-1930s wage compression also becomes important in explaining the decreasing top shares. The drops in capital shares fit well with sharp decreases in top wealth shares during the first half of the century, in particular in the years just after World War I and in the early 1930s, but notably not during World War II, as was the case in many other countries. Between 1950 and 1980 the continued decrease in inequality was quite steady but smaller relative to the first half of the century. Over the past two decades the general picture turns out to depend crucially on how capital gains income is treated. If we include capital gains, Swedish income inequality has increased quite substantially; when excluding it top income shares seem relatively stable. This indicates that there has been no dramatic wage dispersion in Sweden over the past decades, but at the same time, the gains from exceptionally large increases in asset prices (mainly increases in share prices) have been very unevenly distributed. ${ }^{6}$ This, in turn, suggests that the Swedish case over the past decades is different from both the Anglo-Saxon case as well as from the Continental European case previously identified in the literature. ${ }^{7}$

The remainder of the paper is organized as follows: In Section 2 we discuss the data and methodology used, in Section 3 we present our main findings three two sub-headings; first we account for the evolution of top income shares in terms of gross income from all sources (separating series including and excluding capital gains), second we study the composition of these shares by source, and third we study separate top income series when excluding taxable transfers giving us an income concept closer to market income. ${ }^{8}$ Thereafter we attempt to ac-

\footnotetext{
${ }^{6}$ Our data suggests that these capital gains have accrued to those who also have the highest wages, hence magnifying inequalities in the income distribution.

${ }^{7}$ See, for example, Saez (2004) and Piketty and Saez (2006) for overviews of comparisons between different countries.

${ }^{8}$ For most other countries this distinction is not very important when studying top incomes, but in the Swedish context (taxable) social transfers are sufficiently large to have an effect on the top income shares, even if they do not make up any large part of top incomes, as including them affects the reference total for income (see, for example, Björklund and Freeman (2006) on the importance of transfers for income distribution in Sweden). All
} 
count for our results in Section 4 by studying changes in factor shares, the wealth distribution, tax progressivity, and changes in asset prices. We also address the question of what our series suggest regarding the Kuznets hypothesis. In Section 5 we highlight differences and similarities in our results for Sweden with the findings in a number of other countries for which comparable data exist. Section 6 concludes.

\section{Methodology and Data}

In recent years, a methodology for studying income concentration using long time series of tax return data has been established following Piketty (2001), who in turn builds on the seminal work by Kuznets (1953). The basic idea is to construct shares of total personal income received by different fractiles of the entire (tax) population, had everyone been required to file taxes. Since historically only top income earners were taxed they are the only ones directly observed over the entire period. This in turn means that the reference totals for population and income, which are aimed at also including non-filing people and their incomes, must be constructed using aggregate sources from the population statistics and national accounts. Top income shares are then computed by dividing the number of tax units in the top, and their incomes, with the reference tax population and reference total income. ${ }^{9}$ Assuming that top incomes are approximately Pareto distributed, standard inter- and extrapolation techniques can be used to calculate the income shares for various top fractiles, such as the top 10 percent (P90-100) or the top 0.01 percent (P99.99-100).

Our data on income distribution come from the official Swedish income statistics, which provides tabulations of the number of taxpayers and their total assessed income for a large number of income brackets. These tables also typically include information on the different sources of income (e.g., wages and capital income), tax liabilities, and even data on net per-

details of the series as well as various robustness checks have been placed in a separate working paper, Roine and Waldenström (2006).

${ }^{9}$ There are, of course, a number of potential problems with using tax statistics data; it is collected as part of an administrative routine in which individuals have incentives to underreport income, it tells us nothing per se about the welfare of individuals, etc. Nevertheless, as long as we think that tax statistics, at least for the top income earners, approximate actual incomes, and as long as the problems with the statistics have not changed systematically over time, they are a useful source. Importantly, it is also the only available source for much of the twentieth century. Our general view in the case of Sweden is that the administrative process has, compared to most countries, been very thorough and Swedish tax data is quite reliable, at least for high income groups. The estimates of tax avoidance and evasion that we have found suggest that the levels have not changed in any systematic way over the century. A speculative explanation for this observation would be that as marginal taxes have increased (and hence the incentives to avoid or evade taxes) the administrative systems and control efforts have also been expanded. A quantitatively more important way of "avoiding taxation" in Sweden has probably been to keep wealth and "potential income" in tax exempt institutions and/or firms. 
sonal wealth in different income classes for some years. ${ }^{10}$ To make these data homogenous and comparable over time, a number of adjustments have been made as described in more detail in Table 1. Our preferred concept of income is total (gross) income, defined as income from all sources before taxes and transfers, but deducting deficits at source (mainly interest payments). Capital gains are included in this concept, but the structure of the data allows us to subtract them and construct series both with and without capital gains. ${ }^{11}$ One specific attribute of the Swedish income statistics is that after 1974, new laws made several transfer-like nonmarket incomes such as unemployment compensation, family allowances and sick pay, fully taxable, and hence the tax-based total income concept less like the concept of market income compared to previous years. However, under the assumption that very small fractions of top incomes are constituted by these non-market sources, we have also constructed series using an income concept closer to market income by subtracting the aggregate amount of the nonmarket sources from the reference income total after 1973. ${ }^{12}$ Concerning coverage, yearly data are available only from 1943 and for the earlier years we use a number of special investigations made by the statistics authorities or the Ministry of Finance. ${ }^{13}$

Table 1 about here

To calculate the reference totals for income there are basically two ways in which to proceed: either one starts from total income reported on tax returns and then add items not included in the tax base as well as income estimates of individuals not filing taxes (not including children), or one may start from the National Accounts item "Total Personal Sector Income" from which all that is not included in the preferred definition of income can be deducted. Thanks to the relative richness of Swedish historical tax data and national accounts, we have been able to calculate our reference total for income in a number of ways and our final preferred series

\footnotetext{
${ }^{10}$ Between 1910 and 1948 Sweden had a peculiar kind of wealth tax, which operated through an addition of a fraction (1/60 until 1938, thereafter 1/100) of taxable wealth to total income to get "taxable income". This creates problems in terms of having to adjust tax data to get actual incomes (without the wealth shares) but it also means that information on wealth distribution by income class is available.

${ }^{11}$ Data on capital gains are available in 1945, 1951, and annually from 1967. In 1945 and 1951, the capital gains shares were very low for all fractiles. We use the 1945 shares as estimates for all prior years (see Roine and Waldenström, 2006, for more details).

${ }^{12}$ For some years we have direct observations on the size of transfers by income class and this data supports the assumption that these transfers constitute very small shares of total income in the top of the distribution..

${ }^{13}$ Tax return-based data tabulated in classes of income are available for the years 1903 (only the very top), 1907, 1911, 1912, 1916, 1919, 1920, 1934 and 1941. Since tax returns formed the basis for the income distribution estimates in the Censuses (Folkräkningen), we also have data from 1920, 1930, 1935, 1945 and 1950.
} 
combine both ways of constructing the reference total for income. ${ }^{14}$ When creating a series for the reference tax population, we incorporate the fact that the Swedish tax law (and published income statistics) changed from being family-based, in which married couples were assessed jointly, to being individual-based. Our reference population total, hence, shifts from being the adult population (16 and above) minus married women, to the entire adult population (16 and above). ${ }^{15}$ To get a sense of the size of the fractiles and what it takes in terms of income to be part of a particular income share today, Table 2 presents some descriptive statistics for 2003. As the incomes are highly dependent on whether capital gains are included or not we have included both in the table.

Table 2 about here

\section{The Basic Facts}

\subsection{Top income shares 1903-2004}

Figure 1 shows the evolution of the top decile income share in Sweden over the period 19032004. The broad trend is that this share has been divided by a factor of two over the first eighty years, from around 46 percent of total income in the first years of the century, to 23 percent in 1980. Approximately two thirds of this decline took place before 1950, with large falls in the volatile years just after World War I (1919-1920), and in the years after World War II (1945-1951). This means that most of the drop in pre-tax income inequality took place before the expansion of the welfare state. The decline thereafter is more stable with a new relatively sharp drop in the late 1960s and over the 1970s to a lowest point around 23 percent in the early 1980s. ${ }^{16}$ After the mid-1980s the trend depends crucially on the treatment of capital gains incomes. When these are included, the income share for the top ten percent increases

\footnotetext{
${ }^{14}$ Our main sources for calculating the reference income total are the new National Accounts data for Sweden compiled by Edvinsson (2005) and Swedish tax statistics (Skattetaxeringen till inkomst och förmögenhet, various years). For details see Roine and Waldenström (2006), where we also show that our findings are robust to alternative specifications of this reference total.

${ }^{15}$ The main source for our reference population series are Statistics Sweden, Population Statistics (SCB, Programmet för befolkningsstatistik). The shift from family- to individual-based taxation happened gradually between 1952 and 1970. We constructed a number of alternative reference totals to capture the possible variations across the different legal regimes, but found no significant effects on our basic findings. Moreover, we also changed the age cutoff of the adult population from 16 years to 20 years, which lowered top income shares by roughly five percent for the post-1951 period for which there are detailed age data.

${ }^{16}$ The period between 1951 and 1971 is potentially problematic as Swedish data gradually move from a familyto an individually-based tax system (even though the legal change happens in 1967, when individual tax filing was made optional, and 1971 when it became compulsory). We have tried a number of different specifications for dealing with this gradual change, and while the levels may change over this period by as much a ten percent, the trend and our qualitatively results are not altered; see Roine and Waldenström (2006) for details.
} 
substantially, but when capital gains are excluded the top share remains quite stable, though it does increase slightly (we will analyze this in more detail in section 3.2). The peaks in 1991 and 1994 in the series including capital gains are well known effects due to tax reforms which made it profitable to sell assets in these years.

Figure 1 about here

Even though this development in itself reveals a number of interesting facts, it turns out that decomposing the top decile is crucial for understanding the development. Figure 2 shows the evolution of the income shares for P90-95, P95-99, and P99-100 respectively. Looking first at the decline over the first eighty years of the century, we see that virtually all of the drop in the top decile income share is due to a decrease in the very top of the distribution. The income share for the lower half of the top decile (P90-95) has been remarkably stable, hovering around 10 percent over the entire period, while the P95-99 share declines gradually from about 15 percent of total income in the beginning of the twentieth century to around 10 percent in the early 1980s, with the sharpest drop over the 1970s. In contrast, the top percentile income share is divided by at least a factor of four, dropping from above 20 percent in the early 1900s, to around 7 percent in early 1950s, to a low of 4.7 percent in the beginning of the 1980s. Over the past decades the pattern is similar; P90-95 is stable (whether including capital gains or not), P95-99 increases slightly as does P99-100 when excluding capital gains, but the major difference appears only when including capital gains for the top percentile. Over several years in the late 1990s the income share of the top percentile is about twice as large when including capital gains compared to excluding them.

Figure 2 about here

The above becomes even starker when we consider higher fractiles within the top percent. Figure 3 shows the income share top 0.01 percent of the income distribution. This share was divided by a factor of about eight over the first half of the century, from above 3 percent of income to around 0.4 percent in the early 1950s. Given that most of the income in the very top consists of capital income it is interesting to note that the major falls take place during the financial crises after World War I, in the early 1930s, and after World War II, but notably, not during World War II. This period (1939-1945), which in many other countries was one of major cuts in top income shares, seems to have been a period of relative stability for the very 
top groups in Sweden. From the 1950s the P99.99 income share continues to decline steadily to their lowest points in the late 1970s after which it recovers, reaching new peaks at the time the stock market boom around 2000 given that we include capital gains. If we compare the incomes share for this top group when including and excluding capital gains respectively, the difference is a factor ten in order of magnitude, which again highlights the impact of capital gains in Swedish top incomes. Expressing the incomes of the top 0.01 percent group in multiples of average income, our data suggests that over the twentieth century their income has gone from being around 300 times the average income in the early 1900s, falling down to around 25 times average income in the 70 s, and then rising to more than 100 times average income in the late 1990s (again when including capital gains).

Figure 3 about here

\subsection{Composition of top incomes}

Examining the composition of top incomes is important for the understanding of the development of top income shares. For example, shocks to capital income during World Wars I and II explain much of the decline in French top incomes (Piketty, 2003) while large increases in wage and salaries has been the prime factor behind the increased income inequality in the U.S. during the 1980s and 1990s (Piketty and Saez, 2004). The composition of Swedish top incomes also changes significantly during the twentieth century, and these changes hold important clues for explaining the general patterns.

The sources of income which are distinguished in Swedish tax laws are income from labor (wages and salaries), capital (mainly interest earnings and dividends), business and capital gains. ${ }^{17}$ Table 3 displays the decomposition of the declines in Swedish top income shares (excluding capital gains) of some fractiles between 1912 and 1980. In the period, 1912-1935, basically the entire decrease in total income shares is due to falls in capital income. This explains about two thirds of the drop for the top percentile and above. During the period 19351951 , the falls in total income shares are about the same size as in 1912-1935 (-9.4\% compared to $-12.9 \%$ for P95-99, $-39.3 \%$ compared to $-41.1 \%$ for P99-100), but now with about

\footnotetext{
${ }^{17}$ As discussed in Appendix A in Roine and Waldenström (2006) the Swedish income statistics reported six different sources of incomes until 1990 and only three thereafter. Using available data we are however able to construct consistent and continuous series of the four above-mentioned sources for the entire post-war period. For the earlier periods we rely on data from the censuses (1920, 1930, 1935 and 1945) and estimates of returns to wealth to calculate approximate shares.
} 
half of the decrease attributed to a decreased wage share for top income earners. In the postwar period 1950-1980, the total income shares continue to fall, but now it is not mainly capital shares, nor wage shares, but mainly business income that falls. Over this period business income goes from constituting approximately 20 percent of total incomes in the top decile to being only a couple of percent in $1980 .^{18}$

Table 3 about here

As could be seen in the main series above, the treatment of capital gains is crucial for judging the development of Swedish top income shares after 1980. Capital gains are often excluded from studies of income inequality due to their potentially problematic character (even though they constitute an undisputable part of income according to the classical Haig-Simons definition). Unlike other incomes capital gains are not typically thought of as a flow of income, but rather single realizations of gains potentially earned over a longer period of time. This is most likely true if the capital gains arise from the sale of a house, for example, but it need not be the case if the capital gains instead come from frequent stock market trading. In studies based on tax returns capital gains are sometimes excluded simply because they are not included in the country's income statistics (as in France where they were not subject to taxation before the 1980s) but in most studies series including as well as excluding capital gains have been constructed. As has already been mentioned above, the difference between the series including and excluding capital gains constitute one of the quantitatively most interesting features of recent developments in Swedish top income shares. Even though there is no doubt that some fluctuations (especially the peaks in top income shares in 1993 and 1995 when sales due to tax reasons were relatively attractive) are due to the timing of sales of accumulated wealth, the majority of capital gains earners in the top of the distribution are not likely to be "new" individuals each year, who sell off assets accumulated over a longer period, but are instead those with the highest earnings who year after year make most of their income from capital gains (see Section 4.3 below).

To further illustrate the large differences both within the top decile as well as over time Figure 4 shows the income composition for different fractiles in the years 1945, 1978 and 2004. The general pattern that capital income is more important higher up in the distribution is true for

\footnotetext{
${ }^{18}$ The drop in self-employment income should not be taken as evidence of decreased small-business activity, per se, as self-employed individuals may choose to start a firm from which they pay themselves regular wages, etc.
} 
all of these years. However, between 1945 and 1978 the wage share at all levels of top incomes became more important, while the share of business income decreased at all levels. But in 2004 the pattern is back to that of 1945 in terms of the importance of capital if we include capital gains. In fact, at the very top of the income distribution, the share of capital gains in income today is larger than the return to capital was in 1945.

Figure 4 about here

\subsection{Total income shares vs. market income shares - excluding taxable transfers}

In 1974 a number of work-related transfer programs, such as unemployment insurance, sickness payments, and parental leave payments, became taxable. As such programs have grown in importance over time it could be argued that our series of total gross (pre-tax) income shares have gone from being shares of market income (or even factor income) in the earlier parts of the century to being shares of a pre-tax income concept which includes substantial de-facto transfers. To address the impact of these transfers on our income shares we have calculated series in which we exclude the most important transfer payments. ${ }^{19}$ In our basic series above we added the total government outlays for the transfers that were made taxable in 1974 to the reference total for income for the period before 1974. Under the assumption that these transfers made up a negligible share of top incomes before 1974, this adjustment suffices to make the series conform to the current definition of gross pre-tax income. To exclude the transfers we basically do the opposite. Before 1974 we do not make any additions to the reference total for income, while after 1974 we deduct total transfers from the reference total. However, we must now also take care of the fact that transfer incomes, while being small shares of top incomes, are not zero for everyone in the top decile. To correct our shares we rely on exact data on the size of these transfers by income class for the years 1974-1977 and from 1991 and onwards, and estimations for the period in between.

Figure 5 displays the changes in the series for P90-99 and P99-100 (panel a and b respectively) when including these transfers in the income concept (Total income, which are our main series) and when excluding them (Market income). The basic trend is that market income shares go from being relatively equal to total income shares in the 1950 s, starts to grow in the 1970s and are about 20 percent higher in the beginning of the twenty first century. The

\footnotetext{
${ }^{19}$ The most important transfers are unemployment insurance, sickness payments, and parental leave payments. Transfers which are not taxed (such as child benefits, housing benefits, study grants, etc.) never enter our series. See Roine and Waldenström (2006) for details.
} 
marked recent increase is likely to be an effect of large increases in sickness payments. Again, the difference within the top decile becomes apparent. The difference in income share of the P90-99 group when including and when excluding transfers is quite important, much more so than including or excluding capital gains. For the P99-100 income shares the opposite is true. The difference between total income and market income shares are much smaller than that between shares including or excluding capital gains.

Figure 5 about here

\section{Explaining the evolution of top income shares in Sweden}

What accounts for the large declines of top income shares in the first half of the twentieth century, the steady decline during the expansion of the welfare state, the relatively sharp drops over the 1970s, and the conditional increase (only apparent when capital gains are included) in the recent decades? Two aspects, repeatedly stressed above, stand out as key explanatory components. First, the secular decline in income inequality is largely driven by decreases in the top one percent of the income distribution, and second, these changes are in turn to a large extent driven by changes in income from capital. Similarly, the increase in top income shares over the past decades is also almost entirely a top percentile phenomenon and largely due to capital gains income.

In this section we will discuss different factors that can contribute to our understanding of the evolution of the top income shares presented above. First, we examine the roles of factor shares and wealth distribution, and their respective changes over time. In particular, the Swedish tax system before 1948 provides us with data on wealth by income class. Second, we map the evolution of the Swedish progressive income tax system, and third, we account for the recent dramatic changes in asset prices, arguing that these are fundamental for understanding the particular Swedish experience with very large differences in top shares depending on whether capital gains are included or not. Finally, we relate our findings to previous discussions on the Swedish "Kuznets curve". ${ }^{20}$

\footnotetext{
${ }^{20}$ According to Morrison (2000), Sweden is as an example of a country which exhibits an inequality pattern in line with the Kuznets hypothesis between 1870 and 1950.
} 


\subsection{The roles of factor shares and the wealth distribution}

According to David Ricardo, "the principal problem of Political Economy [...] is to determine how [...] the produce of the earth ... is divided between ... the proprietor of the land, the owner of the stock of capital needed for its cultivation, and the labourers by whose industry it is cultivated". ${ }^{21}$ If we were to assume that the very top of the income distribution consists of mainly of wealth holders, while the rest of the population consists mainly of wage earning workers, fluctuations in factor shares should also explain fluctuations in income shares. (We shall return to the question of how good an approximation this is below). Figure 6 shows the changes in the capital share of value added (defined as GDP by activity, minus wages and salaries, minus imputed labor income of self-employed) as a share of GDP, and the evolution of the top one percent income share.

Figure 6 about here

The correlation between the two series over the whole period is 0.86 , but with a clear difference between the first and second half of the century. Between 1907 and 1950 the correlation is 0.94 , while it drops to 0.55 between 1951 and 2000. This indicates that, at least during the first fifty years, even short term fluctuations of top incomes follow the fluctuations of the capital share of value added as a share of GDP. The figure also shows a downward trend in the capital share of value added over the first 80 years and a conservative reading would suggest a drop in this share from around 0.35 in the first decade, to approximately 0.25 in the 1970 s and 1980s. ${ }^{22}$ If we were to take this share as a proxy for the share of GDP derived as a return to property it would translate directly to an equally large drop in the income share of property holders who, in turn, are found mainly among the top income earners. These relationships are, of course, not as simple as suggested by quoting Ricardo above, firstly because no income class consists of only wage earners or only property holders, and secondly because a number of institutions (such as firms and the government sector) stand between the productive sector and the personal sector who's income distribution we are concerned with. But,

\footnotetext{
${ }^{21}$ Originally quoted in Atkinson (1975, p 161).

${ }^{22}$ The question of factor shares, to what extent they are relatively stable over time, and how "relatively stable" should be interpreted, is of course a much debated question. See Atkinson (1975, chapter 9), for a good overview and a historical perspective, where it is also noted that the labor share seems to have been increasing at least since the 1930s up to the 1970s in a number of Western economies.
} 
nevertheless, such approximations give a sense of the magnitude by which the respective factors could have changed the income shares. ${ }^{23}$

In the case of Sweden, however, there exist unusual data on individual wealth holdings by precisely those groups for which we also have income data. The reason is that between the years 1910 and 1948 Sweden had a peculiar form of joint income- and wealth taxation in which taxes were levied on what was called the taxable amount, consisting of all income plus a share of net wealth holdings. For selected years, tabulations of incomes decomposed into actual income and wealth shares by income class are available. ${ }^{24}$ Similar information is also available in the 1950 Census (for the year 1951) and for the years 1991-1993. This allows us to calculate the wealth shares held by top income groups. Figure 7 shows the evolution of wealth shares by income class, together with our calculations of wealth shares (by wealth class) and income shares (by income class) for P99-100 and P90-99 of the respective distributions. ${ }^{25}$ Not surprisingly, wealth shares by income class follow the fluctuations of income shares closer than do wealth shares, but the trends seem to be the same. The wealth share of the top percent among the income earners, as well as among wealth holders, is decreasing quite dramatically over the century with slight recoveries over the past decades. ${ }^{26}$ The wealth shares for the P90-99 group, both in the income and in the wealth distribution, are instead increasing until around 1950. After that they fall slightly, to recover again after the mid 1980s. Once again this highlights the importance of distinguishing between different groups in the top to understand the trends. In terms of explaining the evolution of income shares these wealth trends are well in line with our findings that almost all of the fall in the top decile in-

\footnotetext{
${ }^{23}$ Among the interesting details found by studying the development of the capital share of value added as share of GDP is that it is likely to explain the peak in the top income share in 1916. The first years of World War I was a period during which industrial companies made huge profits while the majority of the population experienced substantial falls in real wages and trade restrictions that lead to a food shortage (see Edvinsson (2005), p 242, and references given there). The year 1916, which is the only year for which we have data during this period, was most probably the most extreme year. The average wage rate fell by ten percent and the ratio between gross surplus and labor income jumped from about 50 percent in 1914-15, to around 70 percent in 1916-17 (after which it fell back down to 50 percent in 1918-19), indicating that 1916 was a year when the income share of capital owners was very high compared to the years immediately before and after.

${ }^{24}$ The taxable amount was equal to all income plus 1/60th of taxable wealth between 1910 and 1938 and there after all income plus 1/100th of taxable wealth until 1948.

${ }^{25}$ Our series for wealth distribution are based tax return data and are for the years 1920-1975 similar to Spånt (1975) and for the years 1978-2002 to series calculated by Statistics Sweden (2002), rather that more recent estimates based on household panel data (such as Klevmarken, 2004). In the present context these figures are most relevant as we are trying to estimate the impact of wealth concentration on income concentration rather than some measure of living standards.

${ }^{26}$ The top percent wealth share in the wealth distribution has increased over the past decades and assuming that the the wealth of the top income earners has followed this is true for them as well. However, we only have data on the years between 1991 and 1993.
} 
come share stems from the top percentile and that this fall, especially in the first half of the century, is due to decreases in capital income.

Figure 7 about here

What would be the joint impact of the changes in wealth concentration and the changes in factor shares on the income distribution? Following Meade (1964), we can make a simple approximation to get a sense of the magnitude of the effect. Let $a$ and $b$ be the share of all earnings and all returns to property, respectively, received by a certain income group. Then the total income share of this group is given by

$a \cdot($ factor share of earnings $)+b \cdot($ factor share of property).

Taking 0.5 times the wealth share of the top income group as a proxy for $b$, and setting the factor share of property to 0.3 (alternatively letting the factor share fluctuate and take on the yearly value calculated above) we can get a sense of the magnitude of the impact that changes in wealth concentration at the top of the income distribution has had between 1911 and 1991. ${ }^{27}$ Table 4 gives an example of such a calculation for P99-100.

Table 4 about here

Table 4 suggests that the direction of change is correct for all intervals except for the period 1920-1930 when the income share increases slightly for the top percent of income earners but their wealth share drops. Between 1911 and 1920, however, the magnitudes are not right. The income share increases slightly more 1911-1916 and, in particular, drops much more 19161920 than what can be explained by changes in wealth shares. The results for the period 1930-1935 plausibly suggests that most of the fall in the top income shares 1930-34, as well as the recovery 1934-1935 were due to changes in financial wealth. For the period thereafter, 1935-1951 wealth changes played a smaller role in the decreasing top income shares (com-

\footnotetext{
${ }^{27}$ Approximating $b$ by 0.5 times the wealth share is based on assuming that the ratio of financial assets to total assets is about 0.5 (this ratio was 0.49 for households in Sweden in 1995). This figure clearly fluctuates over time and across income groups but as our calculations are only intended to give a sense of magnitude and direction it does not affect the conclusions we draw. The numbers in Table 4 resulting from changes in wealth can be multiplied by 2 to get the impact of assuming $b=$ wealth share, or divided by 2 if $b=0.25$ times wealth share.
} 
pare to Table 3 above) while the changes in wealth in the period 1951-1991 suggests that top income shares should have fallen more than they did.

Overall, the above suggests that an important reason for the substantial drop in the top one percent income share - which is driving the decreased income share of the top ten percent especially before 1950 , is the decreased wealth share of the top income earners, which in turn decreased their share of returns to property. However, the question of why the top wealth share decreased so substantially has no obvious answer. Sweden did not take part in World War I or World War II and even though the country's economy was of course not unaffected by these events, the wars did not cause the same direct destruction of capital in Sweden as they did in many other countries. If single events are to be pointed out, the crises just after World War I and the effects of the Great Depression, which hit Sweden in 1931, and in particular the dramatic collapse of the industrial empire controlled by the Swedish industrialist Ivar Kreuger (the "Kreuger-crash") in 1932 are probably most important. ${ }^{28}$ Between 1908 and 1920 we see considerable drops in top wealth shares but not a corresponding drop in wealth holdings of the top percent income earners between 1911 and 1920 (though there is a considerable drop from the peak in 1916). ${ }^{29}$ Between 1930 and 1935 we observe a drop from 50 percent to 43 percent in the top percent wealth share but an even larger drop in the wealth of the top one percent of income earners, from 38 percent in 1930 to 26 percent in 1934 (see Figure 7 above). World War II, however, does not seem to have been a major shock to wealth holdings in Sweden. The top one percent share does drop from 43 to 37 percent between 1935 and 1945, but the drop just after the war is just as sharp continuing down to 32 percent in 1950 (see Section 5 for more on this point in international perspective). The movements for top wealth shares by income class are similar. Overall, during the first half of the twentieth century the top percentile wealth shares, both in the wealth distribution and in the income distribution, were divided by a factor two. By 1950 progressive taxation has started to play a major part and the most likely explanation of the continued decreasing top wealth share is that a larger share of new wealth is accumulated in the corporate and government sector and among the rest of the population, rather than in the wealthiest percent.

\footnotetext{
${ }^{28}$ In Sweden, the economic crisis in the early 1920 s was in many ways more severe than the one ten years later which coincided with the "Great Depression" in America.

${ }^{29}$ There could be problem in the data as the sources for 1911 and 1912 for wealth by income class are tax return data for the first two years when the wealth tax was implemented, which could underestimate the wealth in the top shares, while the 1908 wealth data is based on estates. By 1920 the system of joint income and wealth taxation was well established and wealth data was also collected for the Census which leads us to think that these series are relatively reliable at least from that point on.
} 


\subsection{The role of taxation}

Many previous studies have shown that top incomes are sensitive to changes in top marginal income tax rates, either through their direct effect on work incentives or through more subtle processes of tax arbitrage (see Saez (2004) for an overview of this literature). For example, Saez and Veall (2005) showed that Canadian top income shares were negatively correlated with Canadian marginal income tax rates, with elasticities of income with respect to the netof-tax rates for the top 1 percent being about unity.

In the case of Sweden, Figure 8 depicts the statutory marginal tax rates for incomes at the 90th, 99th, 99.9th and 99.99th percentiles over the past century. ${ }^{30}$ These rates started to increase from moderate levels in the second half of the 1930s and more than doubled at all thresholds between 1935 and 1950, reaching 65 percent at P99.99 and close to 30 percent for P90. After 1950 the rise continued, reaching a peak in 1980 at 85 percent for the very top income earners and just above 60 percent for the top decile. After this, marginal taxes were lowered somewhat in the mid-1980s and much more so after the tax reform of 1990-1991. In the post-1990 period, we plot the highest marginal tax rate in the figure although this only applied to earned income (wages and business income) while capital income was taxed separately at a lower, flat rate. The marginal tax on total income after 1990 is hence somewhat lower than the figure shows.

Figure 8 about here

Figure 8 proposes a clear linkage between the developments of Swedish marginal income taxation and top income inequality, at least after World War II. ${ }^{31}$ The fact that there are sharp falls in the very top of the income distribution in the late 1940s, while the sharpest drops in the P90-99 group takes place in the 1970s, fits well with when marginal tax rates are increased the most for the respective groups. However, given that much of the fall in top incomes happens before taxes reach extreme levels and largely as a result of decreasing income from wealth, the major effect of taxation in terms of top income shares has been to prevent the

\footnotetext{
${ }^{30}$ The presented marginal tax rates are the sum of the respective rates at the local (kommunalskatt) and state (statlig skatt) levels, calculated using tables in Söderberg (1996).

${ }^{31}$ A similar linkage was found for Canada by Saez and Veall (2005).
} 
accumulation of new fortunes. To the extent that new fortunes were created they most probably remained in the corporate sector. ${ }^{32}$

To get a better picture of the role of taxation for Swedish top income shares, we estimate tax elasticities in several top income levels for the postwar period (1943-1990) ${ }^{33}$ In particular, we relate the incomes at the 90th, 99th, 99.9th and 99.99th income percentiles (listed in Appendix Table A2) to the statutory marginal tax rate (with both local and state taxes) using data in Söderberg (1996). Then log-linear time series regressions are estimated for each percentile separately, as follows:

$$
\ln \left(S_{P}\right)_{t}=\beta_{0}+\beta_{1}\left(\ln \left(1-M T R_{P}\right)_{t}\right)+\beta_{2} t+\beta_{3} t^{2}+u_{t}
$$

where $S_{P}$ denotes income share for percentile $P=$ P90, P99, P99.9, P99.99, $\left(1-M T R_{P}\right)$ the corresponding net-of-tax rate (one minus the marginal tax rate), $t$ a linear time trend and $u_{t}$ a random error. ${ }^{34}$ We estimate OLS regressions using Newey-West standard errors to correct for serial correlation in the residuals, but since inflation my push up incomes into higher tax brackets ("bracket-creep") and give rise to a too low estimated tax elasticity $\left(\hat{\beta}_{1}\right)$, we also fit two-stage least squares (2SLS) regressions in which log of one minus the highest statutory marginal tax rate is used to instrument for this eventuality. ${ }^{35}$ The results in Table 5 show that the tax elasticity increases in income and that influence bracket-creep is of minor importance (i.e., OLS and 2SLS results are very similar). In the P90 case, the OLS tax elasticity is zero and 0.3 in the 2SLS, but as the Hausman test indicates that the OLS estimate might be biased downward, the higher 2SLS estimate are the more robust one. Altogether, these results are in line with the prior expectations, as well as with findings from estimated tax responses of U.S. top income earners studied by Saez (2004). Progressive taxation hence seems to have been a major contributing factor in explaining the evolution of Swedish top incomes in the postwar period.

Table 5 about here

\footnotetext{
${ }^{32}$ The particular structure of ownership via various tax exempt institutions due to tax reasons have been well documented in, e.g., Henrekson and Jakobsson (2005).

${ }^{33}$ Before 1943, there is no annual data and after the tax reform of 1990-1991, wages and capital income were taxed at separate tax rates.

${ }^{34}$ Equation (1) is inspired by Saez (2004), but unlike him we use threshold incomes and corresponding marginal tax rates instead of average incomes in a group of income earners, say P99-100, and the corresponding weighted average marginal income tax for all the various income levels contained in the top percentile group.

${ }^{35}$ Bracket-creep is when inflation pushes incomes up in higher tax brackets and increases the marginal tax rate automatically.
} 


\subsection{The role of asset prices}

One aspect which stands out in our series over the past decades is the large difference in top income shares between including and excluding capital gains income. Whether capital gains should be included in the income concept is debatable and ultimately depends on the questions at hand. ${ }^{36}$ When it comes to studying Swedish income inequality, and in particular in the absolute top over recent decades, we argue that capital gains incomes are too important to be ignored. Our main motive for this is the development of Swedish stock prices, which in comparison with any other Western economy stand out as remarkable. ${ }^{37}$ Figure 9 shows the evolution of the composite stock price index, in real terms, at the Stockholm Stock Exchange and three top income fractiles belonging to different part of the top decile since 1967 (which is the first year with separate capital gains figures for different total income classes). The figure clearly suggests that the capital gains accruing to the top income earners to a large extent emanate from value increases of financial holdings, and for each fractile the correlation with the stock price index is over 0.90 and highly significant. ${ }^{38}$

Figure 9 about here

One of the major concerns with including capital gains in the analyzed total income concept is the possibility that some tax payers in the top income fractiles are there only because of recent realizations of gains that have been accumulated over a longer period of time. However, using tabulated income data listing capital gains earnings in classes of labor income (which excludes capital gains), we can, at least after 1990, confirm that this is not the case for the most part of our analyzed capital gains incomes. ${ }^{39}$

Altogether, our data suggest that the substantial increases in capital gains that drive much of the observed rise in top income shares in Sweden over the past decades is entirely due to in-

\footnotetext{
${ }^{36}$ See for example Atkinson (1975), Chapter 3, for a general discussion and, in particular Björklund, Palme and Svensson (1995) for a discussion of the effects from including income from real capital in the Swedish case.

${ }^{37}$ Over the period 1980-2000, the real stock price index at the Stockholm Stock Exchange increased 20 times while the same indexes in New York, London and Paris increased four to six times over the same period.

${ }^{38}$ Compared to real estate prices, which have also increased substantially over the past decades (starting at 100 in 1981, the housing price index was 360 while the consumer price index was 250, in 2003) the gains from equities are much larger and also much more concentrated. However, it is likely that the increase in wealth holdings for the top ten percent (even when excluding the top percent) is largely due to the increases in owner occupied housing prices.

${ }^{39}$ Looking at the average realized capital gains over labor income classes, the overwhelmingly largest average capital gains in the entire period 1991-2004 accrue to those who already are positioned in the top of the income distribution. See Roine and Waldenström (2006, appendix ) for details.
} 
creases financial asset prices on the Swedish stock market. The question of how top income shares have developed over the past decades can not be answered in a satisfactory manner without making the answer conditional on the inclusion of capital gains.

\subsection{Our series and the Kuznets hypothesis}

The development of Swedish income inequality has previously been suggested to display support of the Kuznets hypothesis, i.e., that income inequality is inversely U-shaped over the path of development. ${ }^{40}$ For example, in his study of salaries across sectors, Söderberg (1991) found that inequality increased from 1870 to 1914, dropped sharply during World War I, increased again between 1920 and 1930 before it turned down for the rest of the studied period until 1950. As industrialization in Sweden started around 1870 and peaked around the turn of the century, the increase in income inequality between 1870 and 1914 and the declining thereafter, has been interpreted as an example of Kuznets' curve,

We have so far in this analysis mainly tried to find explanations to the observed secular decline in Swedish top income inequality over the century, and found that drops in top capital income and the rise of progressive taxation have played a large role. Do these findings contradict Kuznets' hypothesis, which rather focuses on changing differentials in wages across workers with differing skill composition? Not necessarily. We can use the historical fact (recall section 3.2) that wages constituted almost all of the incomes going to the high-income groups just below the absolute top, e.g., the P90-95 group, who, if any, in our data represent the highly skilled workers in Kuznets model. Although Figure 2 above showed that their share of all incomes remained remarkably stable of the century, when relating their incomes to the rest of the (mainly) wage earning population, i.e., P0-90, Figure 10 depicts a relationship that could be interpreted as support for a Kuznets curve. Specifically, it shows the ratio between the income shares of $\mathrm{P} 90-95$ and $\mathrm{P} 0-90$ and the downward sloping pattern seems to be in line with what has previously been found by Söderberg (1991). ${ }^{41}$

Figure 10 about here

\footnotetext{
${ }^{40}$ See the section on Sweden in Morrison (2000).

${ }^{41}$ The data in the figure is excluding capital gains (we will study series when including capital gains for the other countries below). The pattern is similar when we instead look at the ratio between average income in P90-95 and that of P0-90 as well as when calculate this ratio using earned income only.
} 
Our data, hence, suggest two things with respect to the Kuznets hypothesis. First, if we exclude the capital owners at the top of the distribution, and focus on the ratio between two groups whose income mainly consists of wages, those with the highest wages and the rest, we get a pattern consistent with what has previously been found as support for the Kuznets curve. Second, however, these changes are not the main explanation behind the secular decline of inequality in Sweden. Even though we do see movement in what approximately constitute the ratio of income shares of high skilled and low skilled workers, the changes in capital income at the very top of the distribution account for the majority of income equalization.

\section{International comparisons}

In Figure 11 the long-run development of top percentile income shares in a number of Western countries is shown alongside that of Sweden. ${ }^{42}$

Figure 11 about here

Looking at the figure, three broad facts stand out. First, all countries experience a similar development with large decreases in top income shares between the beginning of the 1900s and the mid-1970s. The drop in Swedish top incomes over this period is the largest among all these countries, both in absolute and relative terms, but interestingly, much of the difference between Sweden and the other countries in Figure 11 is established already by 1950. Second, the effect of World War II, which for all countries directly engaged in warfare turned out to be devastating for top incomes (see, e.g., Atkinson and Leigh, 2005; Piketty and Saez, 2006), is practically non-existent in Sweden. Table 6 shows this fact in more detail. During the war, the top income share for P99-100 decreased by between 13 and 40 percent in countries directly involved in warfare, but by less than five percent in Sweden. In the years just after the war, by contrast, Swedish top shares dropped over 27 percent whereas they in other countries decreased less than half of that and, in some cases, even increased by up to 20 percent.

\section{Table 6 about here}

The third fact that stands out in Figure 11 is the divergence after 1980 between one group of countries with significantly increasing top shares; Australia, Canada, U.K. and the U.S., and

\footnotetext{
${ }^{42}$ The figure would look very similar for P90-100 and for P99.9-100.
} 
another group; France, the Netherlands and Spain, where the top shares remain virtually constant. ${ }^{43}$ This division between the "Anglo-Saxon" and "Continental European" experience has received a lot of attention in the previous literature. ${ }^{44}$ As can be seen in the figure, Sweden does not belong entirely to either one of these groups. More precisely, if capital gains are included Swedish top incomes shares have increased so much that the Swedish development resembles that of the Anglo-Saxon group. However, when capital gains are excluded, Sweden looks more like belonging to the Continental European group. This difference in the series is unique to Sweden among the countries for which this distinction has been possible to make. Whether capital gains are included or not makes very little difference to the pattern of development in The U.S., Canada, as well as Spain. ${ }^{45}$

This distinction between series including and excluding capital gains holds an important key to understanding the Swedish development in international comparison. Previous work on top incomes has pointed out that the main change over the twentieth century in Anglo-Saxon countries, and in particular in the U.S. has been the replacement of the rentiers by the working rich in the top of the income distribution (see e.g. Piketty and Saez, 2006). To what extent this in turn depends on increased returns to education and skill-biased technological change is a much debated issue, however, the fact that so much of the increase in the top happens in the very top (top one percent) has made many skeptical of a return-to-education story. ${ }^{46}$ Our data for Sweden also seems to indicate that a skill-biased technological change story is not the most likely explanation for the observed changes. First, as was discussed above the movements for the lower part of the top decile P90-95 account for very little of the top decile income share. This is true both when including and excluding capital gains and, hence, suggests that to the extent that we think that high-skilled workers make up most of this group, their income share has not increased substantially over the past decades. Second, and more important, is the large difference in the development in the top depending on how capital gains are treated. The economic interpretation of this development rests on a distinction which we can not entirely make based on our data. If we believe that much of the observed capital gains, in fact, stem from compensation for work made by e.g. chief-executives and other high income

\footnotetext{
${ }^{43}$ This division has previously been discussed in Saez (2004) and Atkinson and Leigh (2005), who also show that this division remains true when including New Zealand to the "Anglo-Saxon" group.

${ }^{44}$ See e.g. Piketty and Saez (2006).

${ }^{45}$ In the case of France this distinction is not very important, according to Piketty (2001, p. 20n), as the capital gains share is very small even for the top income earners. The same relationship seems true for Germany (Dell, 2005, p. 414, fn.2).

${ }^{46}$ Piketty and Saez (2003) are, for example sceptical of the skill-biased technological change explanation for the U.S. See also Dew-Becker and Gordon (2005).
} 
individuals, then the Swedish development should be seen as resembling the Anglo-Saxon one, with working rich receiving an increasing share of all incomes over the past decades. What makes this interpretation plausible is the observed correlation between capital gains and wage incomes discussed in Section 4, as well as the fact that Sweden has a dual tax system where capital incomes are taxed at lower rates than wage incomes. If, however, these capital gains do not stem directly from work but just from making investments with unusually large pay-offs over the past decades, then our data suggests that the key to becoming rich in Sweden over the past decades has been to invest wisely rather than to work hard.

\section{Summary and conclusions}

In this paper, we have studied the evolution of income concentration in Sweden over the twentieth century. We have presented new series on top income shares, their composition, as well as new data relevant for understanding these developments. We have also tried to put our results in international perspective. Our findings suggest that top income shares in Sweden, like in many other Western countries, decreased significantly over the first eighty years of the century. They did so from levels indicating that Sweden was not more equal than other western countries at the beginning of the twentieth century. Most of this decrease happened before 1950, that is, before the expansion of the Swedish welfare state. As in many other countries, most of the fall was due to decreasing shares in the very top of the distribution (the top one percent), while the income share of the lower half of the top decile (P90-P95) has been extraordinarily stable. Most of the fall is explained by decreased income from capital; however, it does not seem likely that this development in the case of Sweden is due only to shocks to capital holdings (which has been the suggested explanation in some other countries). Even though the crises just after World War I and the financial crises in the early 1930s caused drops in both the wealth holdings and the income shares at the top of the income distribution, shocks like these do not fully explain the drop. In particular, we note that the Second World War had no obvious impact on Swedish top income shares. Instead a very significant drop takes place just after the war, at a time when marginal taxes for the top groups had just risen sharply. A closer look at the composition of the decrease in top income shares also suggest that wage compression was as important as decreased capital incomes between 1935 and 1951.

Even if the evolution of top income shares in Sweden in many ways resembles that in other

Western countries over the first eighty years, there are some important differences. Top in- 
come shares had already by 1950 dropped more in Sweden than in any other country (for which comparable data exist), and the further increases in marginal taxes as well as "solidarity wage policies" caused them to drop even further in the 1970s. However, the most remarkably different aspect in the Swedish data appears over the past decades. During this period, when top income shares increased significantly in Anglo-Saxon countries mainly due to wage increases, while they remained virtually unchanged in Continental Europe, the Swedish development depends entirely on how capital gains are treated. If we include capital gains Swedish top income shares look like the Anglo-Saxon ones, if we do not include capital gains they have increased slightly but still resemble the Continental European experience.

Notwithstanding the problems with including capital gains in a study such as this, we believe there are good reasons to think that our data does capture a real development in terms of top incomes. The main reasons for this include, the exceptional stock market development in Sweden since around 1980, the fact that capital gains are consistently concentrated among those with high earnings income, suggesting that the high capital gains do not mainly accrue to "new individuals" each year, and the fact that the capital gains component in top income shares has been important every year over at least a twenty year period. Assuming that top income shares have risen due to capital gains over the past decades, the interesting question for discriminating between different theories for explaining this increase is to what extent these gains are to be seen as part of the compensation for work efforts, or if most of capital gains are to be seen as unrelated to job performance. Depending on the answer to such questions, the Swedish experience over the recent past may be judged as being more similar to the U.S. and the U.K. than what is usually assumed, or perhaps as a development different from the Anglo-Saxon as well as the Continental European one. One possible interpretation of our data is that top income earners in Sweden have not increased their income share over the past decades through higher earnings but instead by making the right investments.

\section{References}

Alvaredo, Facundo and Emmanuel Saez (2005), "Income and Wealth Concentration in Spain in a Historical and Fiscal Perspective", mimeo, UC Berkeley.

Atkinson, Anthony B. (1975), The Economics of Inequality, Oxford University Press: London.

Atkinson, Anthony B. (2004), "Top Incomes in the UK over the twentieth Century”, Journal of the Royal Statistical Society A 168(2), 325-343. 
Atkinson, Anthony B. and Andrew Leigh (2004), "Understanding the Distribution of Top Incomes in Anglo-Saxon Countries over the Twentieth Century", Working Paper, Nuffield College, Oxford.

Atkinson, Anthony B. and Andrew Leigh (2005), "The Distribution of Top Incomes in New Zealand", Discussion Paper No. 503, Australian National University.

Atkinson, Anthony B. and Andrew Leigh (2006), "The Distribution of Top Incomes in Australia", Discussion Paper No. 514, Australian National University.

Atkinson, Anthony B. and Wiemer Salverda (2005), "Top Incomes in the Netherlands and the United Kingdom over the Twentieth Century", Journal of the European Economic Association 3(4): 883-913.

Bentzel, Ragnar (1953), Inkomstfördelningen i Sverige. Uppsala: Almqvist \& Wiksell.

Björklund, Anders and Richard B. Freeman (2006), "Generating Equality and Eliminating Poverty, the Swedish Way", in Richard B. Freeman, Robert Topel, and Birgitta Swedenborg (eds.) Reforming the Welfare State: Recovery and Beyond in Sweden, (2006), Stockhlom, SNS förlag.

Björklund, Anders and Mårten Palme (2000), "The Evolution of Income Inequality during the Rise of the Swedish Welfare State 1951 to 1973", Nordic Journal of Political Economy 26(2), 115-128.

Björklund, Anders, Mårten Palme and Ingemar Svensson (1995), "Tax Reforms and Income Distribution: An Assessment Using Different Income Concepts", Swedish Economic Policy Review 2(2): 229-266.

Dell, Fabien (2003), "Top Incomes in Germany throughout the Twentieth Century", forthcoming in A.B. Atkinson and T. Piketty (eds.) Oxford: Oxford University Press.

Dell, Fabien (2005), "Top Incomes in Germany and Switzerland over the Twentieth Century", Journal of the European Economic Association 3(2-3): 412-421.

Dell, Fabien, Thomas Piketty and Emmanuel Saez (2005), "Income and Wealth Concentration in Switzerland of the 20th Century", CEPR Discussion Paper No. 5090.

Dew-Becker, Ian and Robert J. Gordon (2005), "Where did the Productivity Growth Go? Inflation Dynamics and the Distribution of Income" NBER Working Paper \#11842.

Edvinsson, Rodney (2005), Growth, Accumulation, Crisis. With New Macroeconomic Data for Sweden, 1800-2000. Stockholm: Almqvist \& Wiksell International.

Gottschalk, Peter and Timothy M. Smeeding (1997), "Empirical Evidence on Income Inequality in Industrialized Countries" in A.B. Atkinson and F. Bourgignon (eds.), The Handbook of Income Distribution." London: North Holland Press.

Gustafsson, Björn and Mats Johansson (2003), "Steps toward equality: How and why income inequality in urban Sweden changed during the period 1925-1958" European Review of Economic History 7(2), 191-211.

Henrekson, Magnus and Ulf Jakobsson (2005), "The Swedish Model of Corporate Ownership and Control in Transition", in H. Huizinga and L. Jonung, eds., Who Will Own Europe? The Internationalisation of Asset Ownership in Europe, Cambridge: Cambridge University Press.

Klevmarken, N. Anders (2004), "On the Wealth Dynamics of Swedish Families, 1984-98", Review of Income and Wealth 50(4): 469-91. 
Kuznets, Simon (1955), "Economic Growth and Economic Inequality", American Economic Review 45(1), 1-28.

Lindbeck, Assar (1997), "The Swedish Experiment”, Journal of Economic Literature Vol. XXXV (September 1997), pp. 1273-1319.

Lindbeck, Assar (2006), "The Welfare State - Background, Achievements, Problems”, (forthcoming in new edition of Palgrave, 2006).

Lindert, Peter H. (2000), “Three Centuries of Inequality in Britain and America”, in Atkinson, A. B. and Bourguignon, F, Handbook of Income Distribution, volume 1, North-Holland, Amsterdam.

Lindstrand, M. (1949). Inkomstfördelningen före och efter kriget. Meddelande från Konjunkturinstitutet, Ser B:10, Stockholm.

Lydall, Harold (1968), The Structure of Earnings, Oxford: Clarendon Press.

Magnusson, Katarina (2004), "Utvecklingen av de högsta inkomsterna i Sverige, 1985-2002”, TCO granskar No. 13/04.

Moriguchi, Chiaki and Emmanuel Saez (2005), "The Evolution of Income Concentration in Japan, 1885-2002: Evidence from Income Tax Statistics”, mimeo, UC Berkeley.

Morrison, Christian (2000), "Historical Perspectives on Income Distribution: The Case of Europe", in Atkinson, A. B. and Bourguignon, F, Handbook of Income Distribution, volume 1, North-Holland, Amsterdam.

Piketty, Thomas (2001), “Income Inequality in France, 1900-98”, CEPR Discussion Paper No. 2876.

Piketty, Thomas (2003), "Income Inequality in France, 1900-1998”, Journal of Political Economy 111(5): 1004-1042.

Piketty, Thomas and Emmanuel Saez (2003) "Income Inequality in the United States, 19131998", Quarterly Journal of Economics 118(1): 1-39.

Piketty, Thomas and Emmanuel Saez (2006) "The Evolution of Top Incomes: A Historical and International Perspective", NBER WP \#1155.

Roine, Jesper and Daniel Waldenström (2006), “Top Incomes in Sweden over the Twentieth Century", Working Paper, Stockholm School of Economics.

Quensel, Carl-Erik (1944) Inkomstfördelning och skattetryck, Lund: Sveriges industriförbund.

Saez, Emmanuel (2004), "Reported Incomes and Marginal Tax Rates, 1960-2000: Evidence and Policy Implications”, NBER Working Paper \#10273.

Saez, Emmanuel and Michael L. Veall (2005), “The Evolution of High Incomes in Canada, 1920-2000", American Economic Review 95(3): 831-849.

Spånt, Roland (1979), Den svenska inkomstfördelningens utveckling 1920-1976, background material to Långtidsutredningen 1979:4, Ds E 1979:4.

Swedish National Tax Board (2004), Skattestatistisk årsbok 2004, Stockholm: Fritze.

Söderberg, Hans (1996), Inkomstskattens utveckling under 1900-talet. En vägvisare för skatteberäkningar åren 1921-1996, Skattebetalarnas förening, Stockholm.

Söderberg, Johan (1991). "Wage differentials in Sweden, 1725-1950, in Y. S. Brenner, H. Kaelble and M. Thomas (eds.) Income distribution in historical perspective, Cambridge, Cambridge University Press. 


\begin{tabular}{|c|c|c|c|c|}
\hline $\begin{array}{l}\text { Income } \\
\text { years }\end{array}$ & $\begin{array}{l}\text { Income concept appearing in } \\
\text { data sources [Swedish term] }\end{array}$ & Adjustments & $\begin{array}{l}\text { Reference total in- } \\
\text { come }\end{array}$ & $\begin{array}{l}\text { Reference total } \\
\text { population }\end{array}$ \\
\hline 1903-1910 & $\begin{array}{c}\text { Taxable income [till statlig } \\
\text { inkomstskatt taxerad inkomst]. } \\
\text { Bascially "Total income". }\end{array}$ & - & \multirow{2}{*}{$\begin{array}{c}\text { Share of "total personal } \\
\text { sector income" (from } \\
\text { National accounts) } \\
\text { adding estimates of } \\
\text { items not included in } \\
\text { the preferred definition } \\
(1903-1942)\end{array}$} & \multirow{3}{*}{$\begin{array}{l}\text { Adult population } \\
(>15 \text { yrs }) \text { minus } \\
\text { married women } \\
\quad(-1951)\end{array}$} \\
\hline 1911-1942 & $\begin{array}{l}\text { Taxable amount [Taxerat be- } \\
\text { lopp] = Taxable income (see } \\
\text { above) + Wealth share (i.e., } \\
\text { share of taxable personal net } \\
\text { wealth) - Some taxes. }\end{array}$ & $\begin{array}{c}\text { Removal of wealth } \\
\text { shares and after } \\
1920 \text { addition of } \\
\text { some municipal } \\
\text { taxes } \\
\end{array}$ & & \\
\hline 1943 & \multirow[b]{2}{*}{$\begin{array}{c}\text { Total income }[\text { Sammanräknad } \\
\text { nettoinkomst }=\text { Total (gross) } \\
\text { income }- \text { Deficits at source }\end{array}$} & - & \multirow{4}{*}{$\begin{array}{c}\text { Tax statistics income } \\
\text { plus estimates of non- } \\
\text { taxed items included in } \\
\text { preferred def. (mainly } \\
\text { corrections for changed } \\
\text { tax treatment of unem- } \\
\text { ployment and sick pay } \\
\text { insurance etc. before } \\
\text { 1974) plus estimated } \\
\text { incomes of "non-filers" } \\
(1943-2003)\end{array}$} & \\
\hline 1951-1970 & & $\begin{array}{c}\text { Age adjustment } \\
\text { (excluding all }<16 \\
\text { years old) }\end{array}$ & & $\begin{array}{c}\text { Adult population } \\
(>15 \text { yrs and above) } \\
\text { less housewives } \\
(1951-1971)\end{array}$ \\
\hline 1971-1990 & $\begin{array}{l}\text { Total (gross) income [Samman- } \\
\text { räknad inkomst] }\end{array}$ & $\begin{array}{l}\text { Subtracting defi- } \\
\text { cits at source }+ \\
\text { Age adjustment }\end{array}$ & & \multirow{2}{*}{$\begin{array}{l}\text { Adult population } \\
(>15 \mathrm{yrs})(1971-)\end{array}$} \\
\hline 1991-2004 & $\begin{array}{l}\text { Total income [Sammanräknad } \\
\text { förvärvs- och kapitalinkomst] }\end{array}$ & Age adjustment & & \\
\hline
\end{tabular}

Note: All concepts are elaborated upon in the appendices of Roine and Waldenström (2006). No age-specific data were available for different income classes until 1951.

Table 1: Definitions and adjustments of the income data and reference totals.

\begin{tabular}{ccccccc}
\hline \hline $\begin{array}{c}\text { Thres- } \\
\text { hold }\end{array}$ & $\begin{array}{c}\text { Income (incl. } \\
\text { capital gains) } \\
\text { SEK }\end{array}$ & $\begin{array}{c}\text { Income } \\
\text { (excl. capital } \\
\text { gains) SEK }\end{array}$ & Fractiles & $\begin{array}{c}\text { N tax units } \\
\text { (individuals) }\end{array}$ & $\begin{array}{c}\text { Ave. Income (incl. } \\
\text { capital gains) } \\
\text { SEK }\end{array}$ & $\begin{array}{c}\text { Ave. Income } \\
\text { (excl. capital } \\
\text { gains) SEK }\end{array}$ \\
\hline & & & Full tax pop. & $7,350,260$ & 206,726 & 200,306 \\
$\mathbf{P 9 0}$ & 353,927 & 345,167 & $\mathbf{P 9 0 - 9 5}$ & 367,513 & 394,425 & 381,380 \\
$\mathbf{P 9 5}$ & 450,396 & 430,427 & $\mathbf{P 9 5 - 9 9}$ & 294,010 & 546,713 & 515,256 \\
$\mathbf{P 9 9}$ & 824,912 & 711,548 & $\mathbf{P 9 9 - 9 9 . 9}$ & 66,152 & $1,212,180$ & 938,828 \\
$\mathbf{P 9 9 . 9}$ & $2,400,593$ & $1,569,954$ & $\mathbf{P 9 9 . 9 - 9 9 . 9 9}$ & 6,615 & $3,527,589$ & $2,071,425$ \\
$\mathbf{P 9 9 . 9 9}$ & $6,986,015$ & $3,463,936$ & $\mathbf{P 9 9 . 9 9 - 1 0 0}$ & 735 & $13,031,444$ & $5,277,839$ \\
\hline \hline
\end{tabular}

Note: The calculations are based on income tax data, with income defined as total income (excluding and including capital gains, ranked in classes of total income including capital gains) before individual taxes expressed in SEK 2003. See Roine and Waldenström (2006) for more details.

Table 2: Top income thresholds and average incomes in Sweden 2003. 


\begin{tabular}{|c|c|c|c|c|c|}
\hline & & \multicolumn{4}{|c|}{ Percentage change in } \\
\hline & & \multirow[t]{2}{*}{ Total income shares } & \multicolumn{3}{|c|}{ with contribution by... } \\
\hline & & & Wages & Capital income & Business income \\
\hline \multirow{4}{*}{ 1912-1935 } & P90-95 & 6.1 & 8.8 & -1.2 & -1.4 \\
\hline & P95-99 & -9.4 & -1.8 & -6.3 & -1.4 \\
\hline & P99-100 & -41.1 & -9.1 & -23.8 & -8.2 \\
\hline & P99.9-100 & -53.0 & -7.2 & -35.2 & -10.6 \\
\hline \multirow{4}{*}{ 1935-1951 } & P90-95 & 0.3 & -2.6 & -4.6 & 7.5 \\
\hline & P95-99 & -10.0 & -9.9 & -7.6 & 7.4 \\
\hline & P99-100 & -38.6 & -16.7 & -19.4 & -2.5 \\
\hline & P99.9-100 & -56.2 & -21.8 & -27.0 & -7.3 \\
\hline \multirow{4}{*}{ 1951-1980 } & P90-95 & -2.5 & 11.9 & 0.7 & -15.1 \\
\hline & P95-99 & -11.7 & 11.6 & -1.5 & -21.8 \\
\hline & P99-100 & -36.1 & -6.6 & -4.9 & -24.6 \\
\hline & P99.9-100 & -49.5 & -19.8 & -5.0 & -24.7 \\
\hline
\end{tabular}

Note: Calculations are based on tax returns data from 1945 onwards and Census data from 1920, 1930, 1935 and 1945, including estimates of returns to wealth. Business income is calculated as a residual prior to 1951.

Table 3: Decomposition of changes in Swedish top income shares into wage-, capital- and other incomes over three sub-periods between 1912 and 1980.

\begin{tabular}{c|ccc}
\hline \hline Period & $\begin{array}{c}\text { Change in P99 } \\
\text { income share* } \\
\text { (percentage points) }\end{array}$ & $\begin{array}{c}\text { Change resulting from changes } \\
\text { in wealth (assuming factor } \\
\text { share 0.3, percentage points) }\end{array}$ & $\begin{array}{c}\text { Change resulting from changes } \\
\text { in wealth (calculated factor } \\
\text { shares, percentage points) }\end{array}$ \\
\hline $\mathbf{1 9 1 1 - 1 2}$ & 1.36 & 0.52 & 0.92 \\
$\mathbf{1 9 1 2 - 1 6}$ & 7.12 & 4.36 & 7.76 \\
$\mathbf{1 9 1 6 - 1 9}$ & -11.70 & -2.57 & -5.14 \\
$\mathbf{1 9 1 9 - 2 0}$ & -2.85 & -0.59 & -1.79 \\
$\mathbf{1 9 2 0 - 3 0}$ & 0.26 & -0.58 & -1.29 \\
$\mathbf{1 9 3 0 - 3 4}$ & -1.80 & -1.86 & -2.01 \\
$\mathbf{1 9 3 4 - 3 5}$ & 0.37 & 0.52 & 0.76 \\
$\mathbf{1 9 3 5 - 4 1}$ & -2.03 & -0.39 & -0.17 \\
$\mathbf{1 9 4 1 - 5 1}$ & -3.21 & -0.64 & -0.60 \\
$\mathbf{1 9 5 1 - 9 1}$ & -1.26 & -1.87 & -2.44 \\
\hline \hline
\end{tabular}

Sources: Own calculations based on income and wealth shares reported above.

* Changes based on the series including capital gains. The calculated change in the P99-100 income share between 1951 and 1991 is based on an average of the share in 1990-1992 as 1991 is an outlier in the series including capital gains (as discussed in Section 3) due to the tax reform.

Table 4: Contribution of changes in the top income earner's wealth shares on their income shares, 1911-1991. 


\begin{tabular}{|c|c|c|c|c|c|c|c|}
\hline \multirow[b]{2}{*}{ Fractile } & \multirow[b]{2}{*}{ Model } & \multicolumn{4}{|c|}{ Coefficient estimates } & \multirow[b]{2}{*}{$\mathrm{R}^{2}$} & \multirow[b]{2}{*}{$\operatorname{Pr} .>\chi^{2}$} \\
\hline & & Constant $\left(\hat{\beta}_{0}\right)$ & Elasticity $\left(\hat{\beta}_{1}\right)$ & $\operatorname{Trend}\left(\hat{\beta}_{2}\right)$ & $\operatorname{Trend}^{2}\left(\hat{\beta}_{3}\right)$ & & \\
\hline \multirow{2}{*}{ P90 } & OLS & $\begin{array}{c}3.51 * * * \\
(0.06)\end{array}$ & $\begin{array}{c}0.07 \\
(0.13)\end{array}$ & $\begin{array}{l}-0.01 \\
(0.01)\end{array}$ & $\begin{array}{l}-0.00 \\
(0.00)\end{array}$ & 0.79 & \\
\hline & 2SLS & $\begin{array}{c}3.53 * * * \\
(0.04)\end{array}$ & $\begin{array}{c}0.30 * * * \\
(0.11)\end{array}$ & $\begin{array}{l}-0.00 \\
(0.00) \\
\end{array}$ & $\begin{array}{l}-0.00 \\
(0.00) \\
\end{array}$ & 0.77 & 0.00 \\
\hline \multirow{2}{*}{ P99 } & OLS & $\begin{array}{c}2.39 * * * \\
(0.08)\end{array}$ & $\begin{array}{c}0.27 * * * \\
(0.10)\end{array}$ & $\begin{array}{c}-0.02 * * \\
(0.01)\end{array}$ & $\begin{array}{c}0.00 * * \\
(0.00)\end{array}$ & 0.88 & \\
\hline & 2SLS & $\begin{array}{c}2.41 * * * \\
(0.05) \\
\end{array}$ & $\begin{array}{c}0.32 * * * \\
(0.06) \\
\end{array}$ & $\begin{array}{c}-0.02 * * * \\
(0.00)\end{array}$ & $\begin{array}{c}0.00 * * * \\
(0.00) \\
\end{array}$ & 0.88 & 0.98 \\
\hline \multirow{2}{*}{ P99.9 } & OLS & $\begin{array}{c}1.43^{* * *} * \\
(0.09)\end{array}$ & $\begin{array}{c}0.53 * * * \\
(0.08)\end{array}$ & $\begin{array}{c}-0.04 * * * \\
(0.01)\end{array}$ & $\begin{array}{c}0.00^{* * * *} \\
(0.00)\end{array}$ & 0.92 & \\
\hline & 2SLS & $\begin{array}{c}1.45^{* * *} * \\
(0.07)\end{array}$ & $\begin{array}{c}0.58 * * * \\
(0.07)\end{array}$ & $\begin{array}{c}-0.04 * * * \\
(0.00)\end{array}$ & $\begin{array}{c}0.00 * * * \\
(0.00)\end{array}$ & 0.92 & 0.87 \\
\hline \multirow{2}{*}{ P99.99 } & OLS & $\begin{array}{c}0.64 * * * \\
(0.10)\end{array}$ & $\begin{array}{c}0.81 * * * \\
(0.09)\end{array}$ & $\begin{array}{c}-0.07 * * * \\
(0.00)\end{array}$ & $\begin{array}{c}0.00 * * * \\
(0.00)\end{array}$ & 0.91 & \\
\hline & 2SLS & $\begin{array}{c}0.71 * * * \\
(0.13)\end{array}$ & $\begin{array}{c}0.89 * * * \\
(0.13)\end{array}$ & $\begin{array}{c}-0.06 * * * \\
(0.00)\end{array}$ & $\begin{array}{c}0.00 * * * \\
(0.00)\end{array}$ & 0.91 & 0.19 \\
\hline
\end{tabular}

$\overline{\text { Notes: OLS regressions use Newey-West standard errors (with } 6 \text { lags). The }} \overline{\overline{2 S L S} \text { instrument the net-of-tax rate }}$ with the $\ln (1-$ Statutory top marginal tax rate). Tax rates are calculated using laws listed in Söderberg (1996). $\operatorname{Pr} .>\chi^{2}$ shows Hausman test of difference between OLS and 2SLS. All regressions have 48 observations. *, **, $* * *$ denote significance at the $10 \%$-, $5 \%$ - and $1 \%$-levels, respectively.

Table 5: Marginal tax effects on Swedish top incomes, 1943-1990.

\begin{tabular}{c|ccccccc}
\hline \hline & \multicolumn{7}{|c}{ Percentage change in the top percentile income share in... } \\
Period: & Sweden & Australia & Canada & France & Netherlands & UK & USA \\
\hline $1939-1945$ & -4.6 & -24.0 & -40.1 & -43.3 & -12.7 & -22.7 & -25.5 \\
$1946-1951$ & -27.2 & 11.4 & -0.9 & 19.4 & -11.2 & -15.2 & -5.3 \\
\hline
\end{tabular}

Note: For Sweden, we use 1941-1945 since no data exist for 1939.

Table 6: Percentage change in top percentile income shares during World War II 


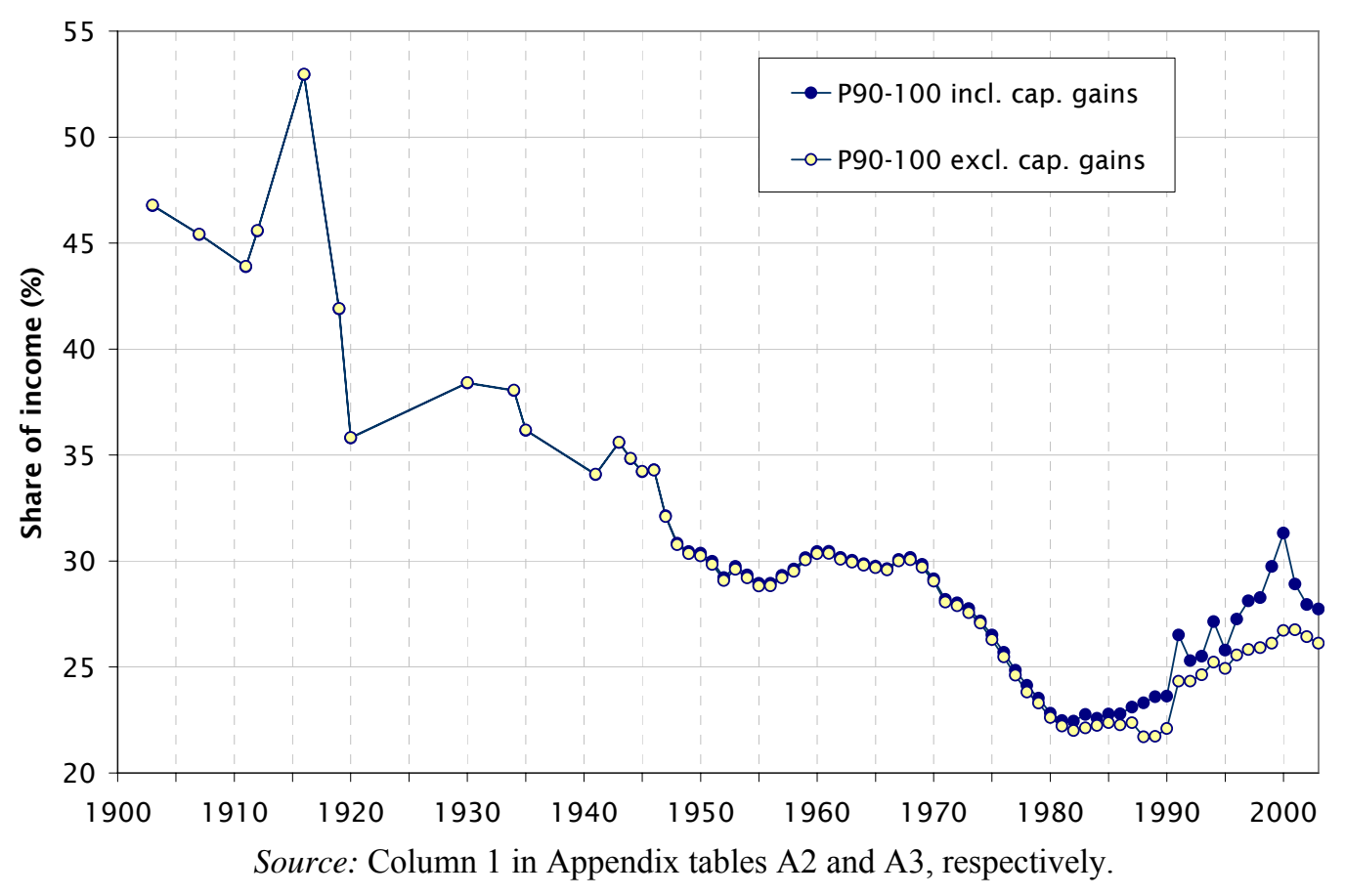

Figure 1: The top 10 percent income share (with and without capital gains), 1903-2004.

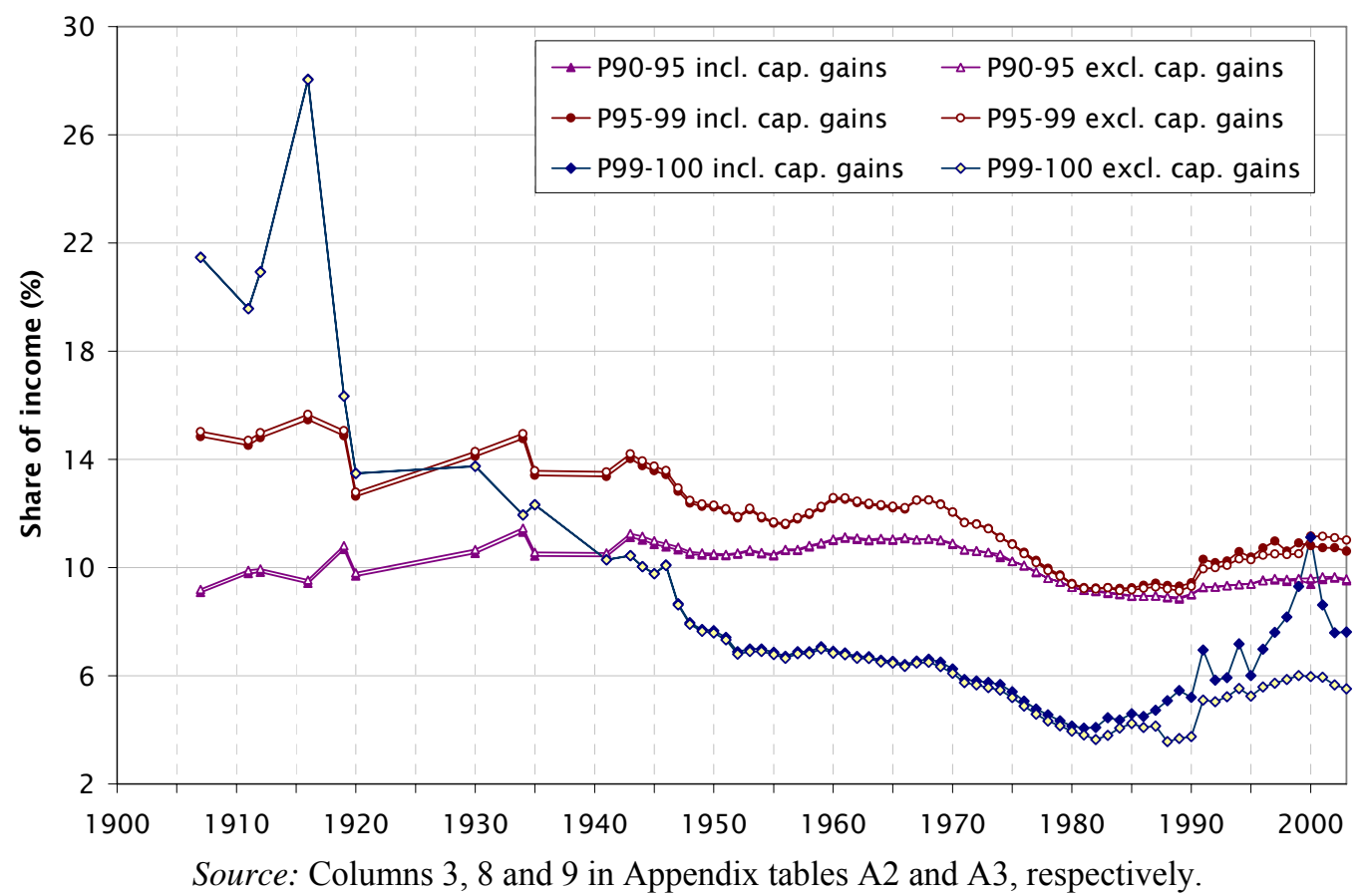

Figure 2: The P90-95, P95-99 and P99-100 (top 1 percent) income shares (with and without capital gains), 1903-2004. 


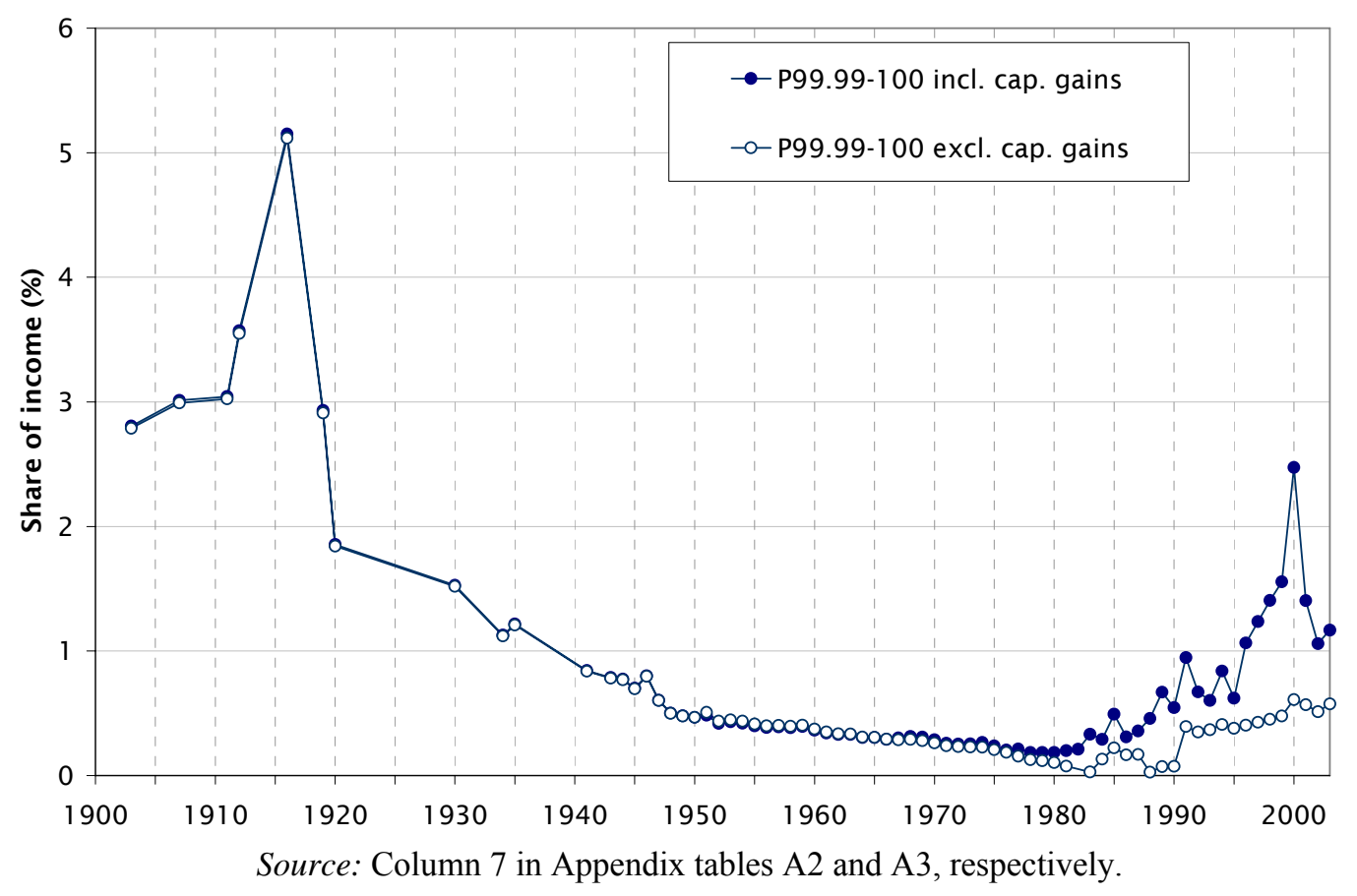

Figure 3: The top 0.01 percent income share (with and without capital gains), 1903-2004. 


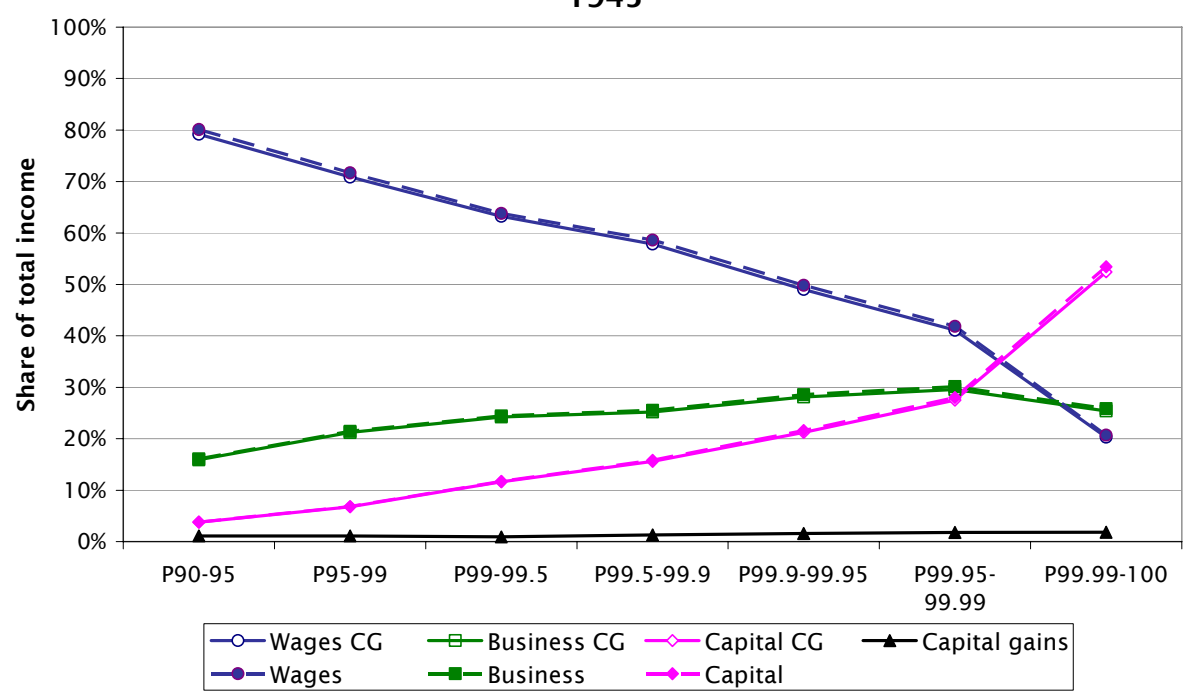

1978

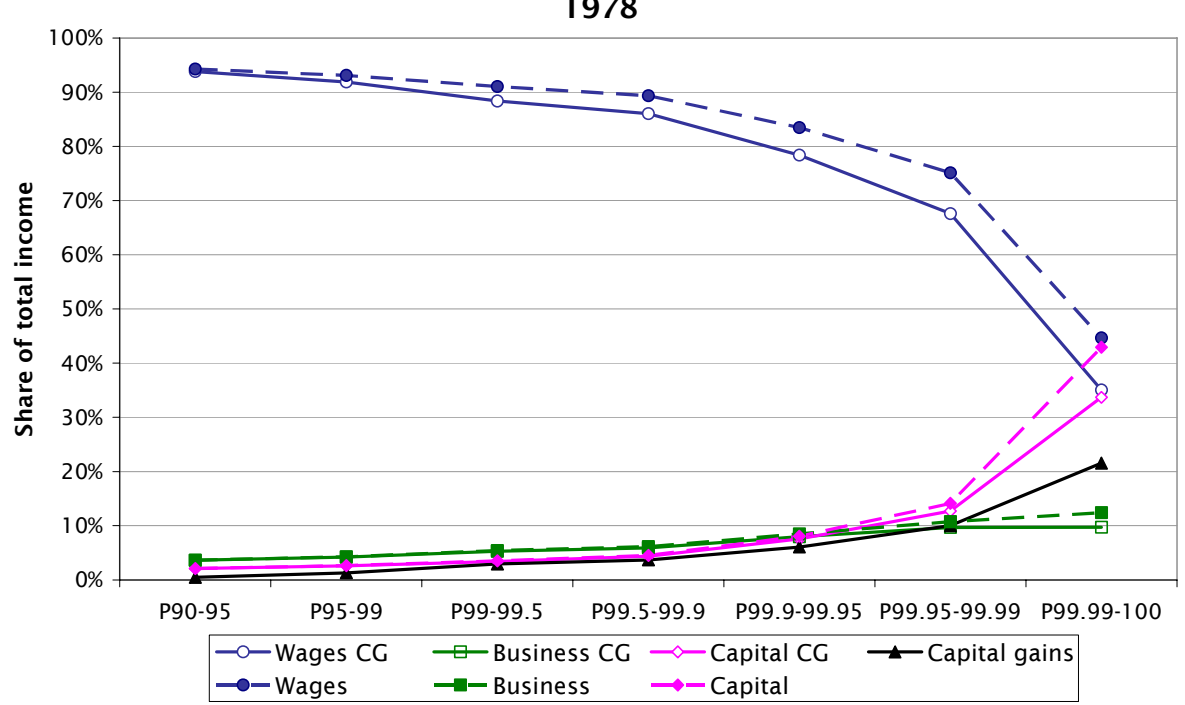

2004

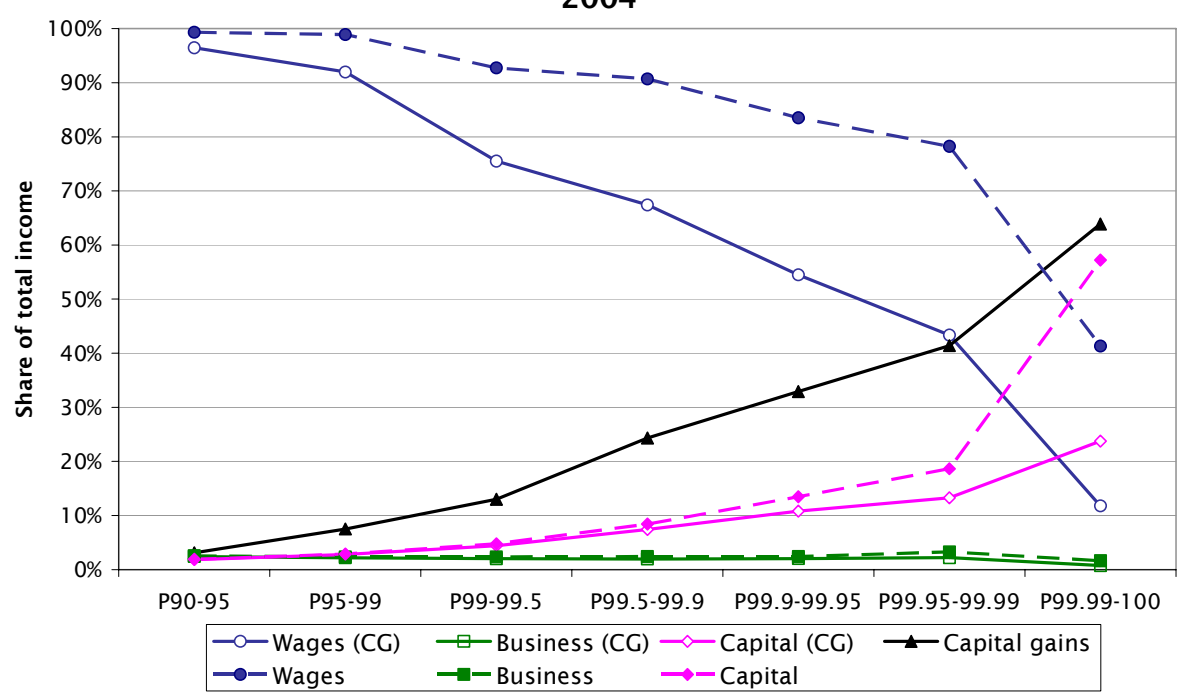

Figure 4: Income composition within the top decile 1945, 1978 and 2004 
a) P90-99

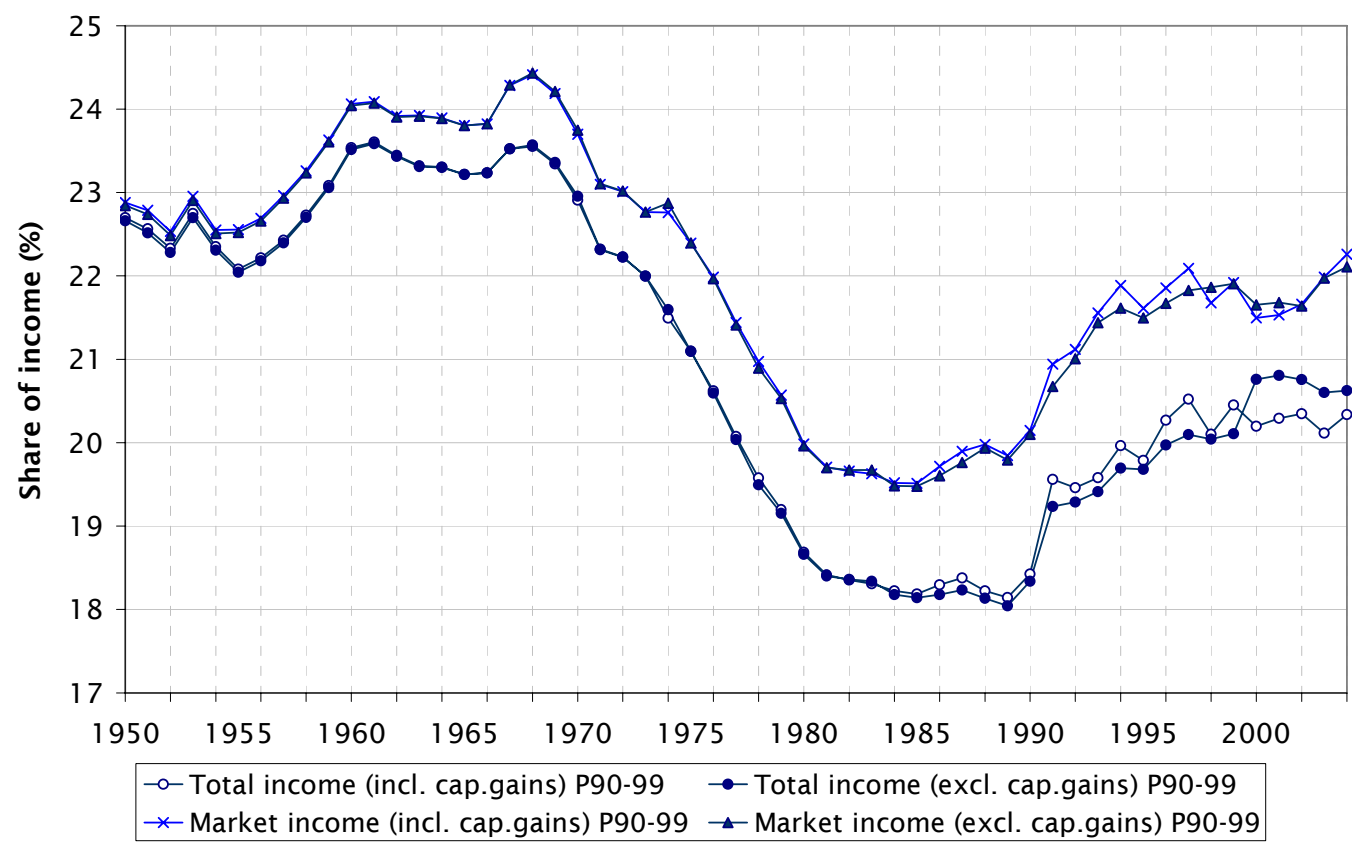

b) P99-100

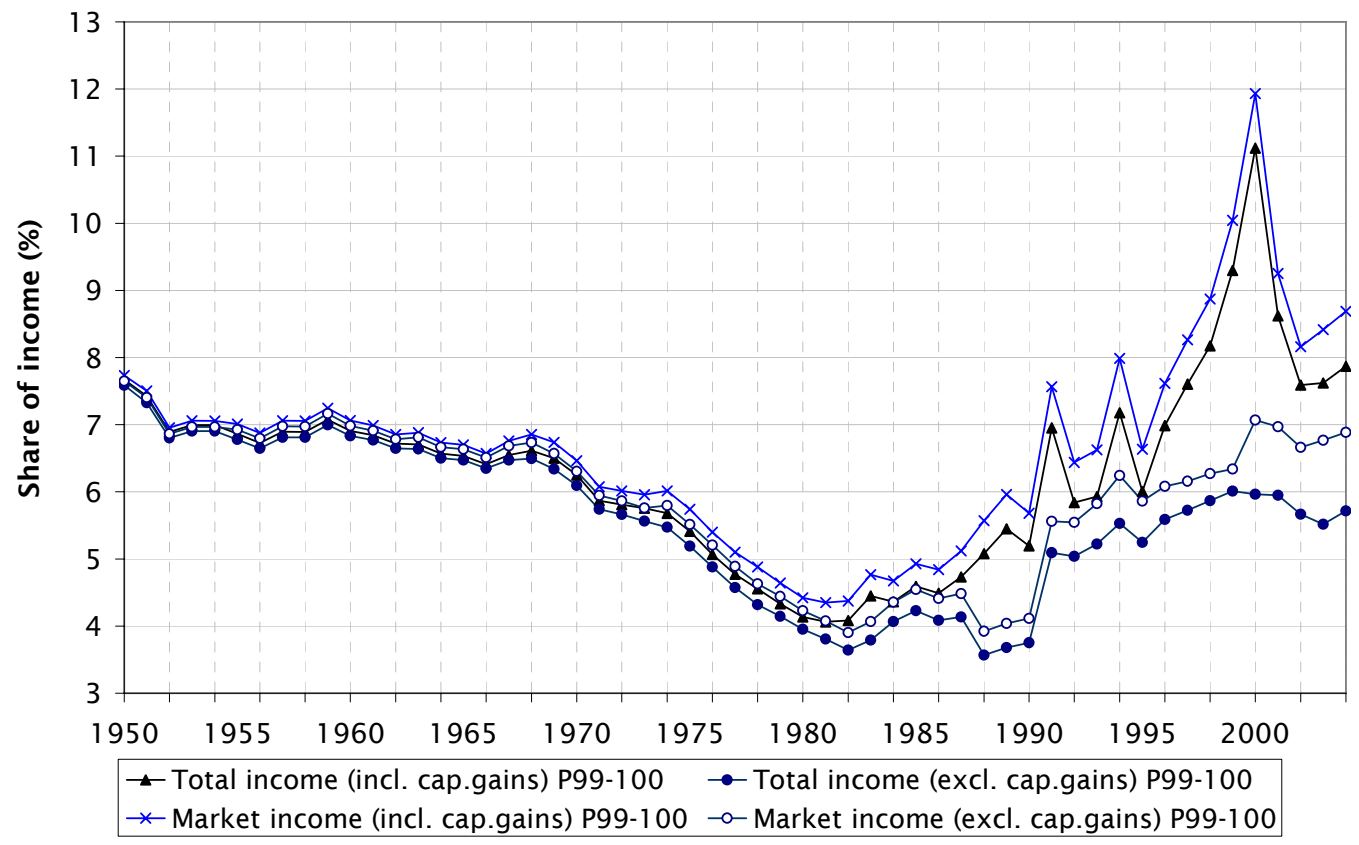

Figure 5: Total income shares vs. market income shares 1950-2004, (panel a, P9099; panel b, P99-100). 


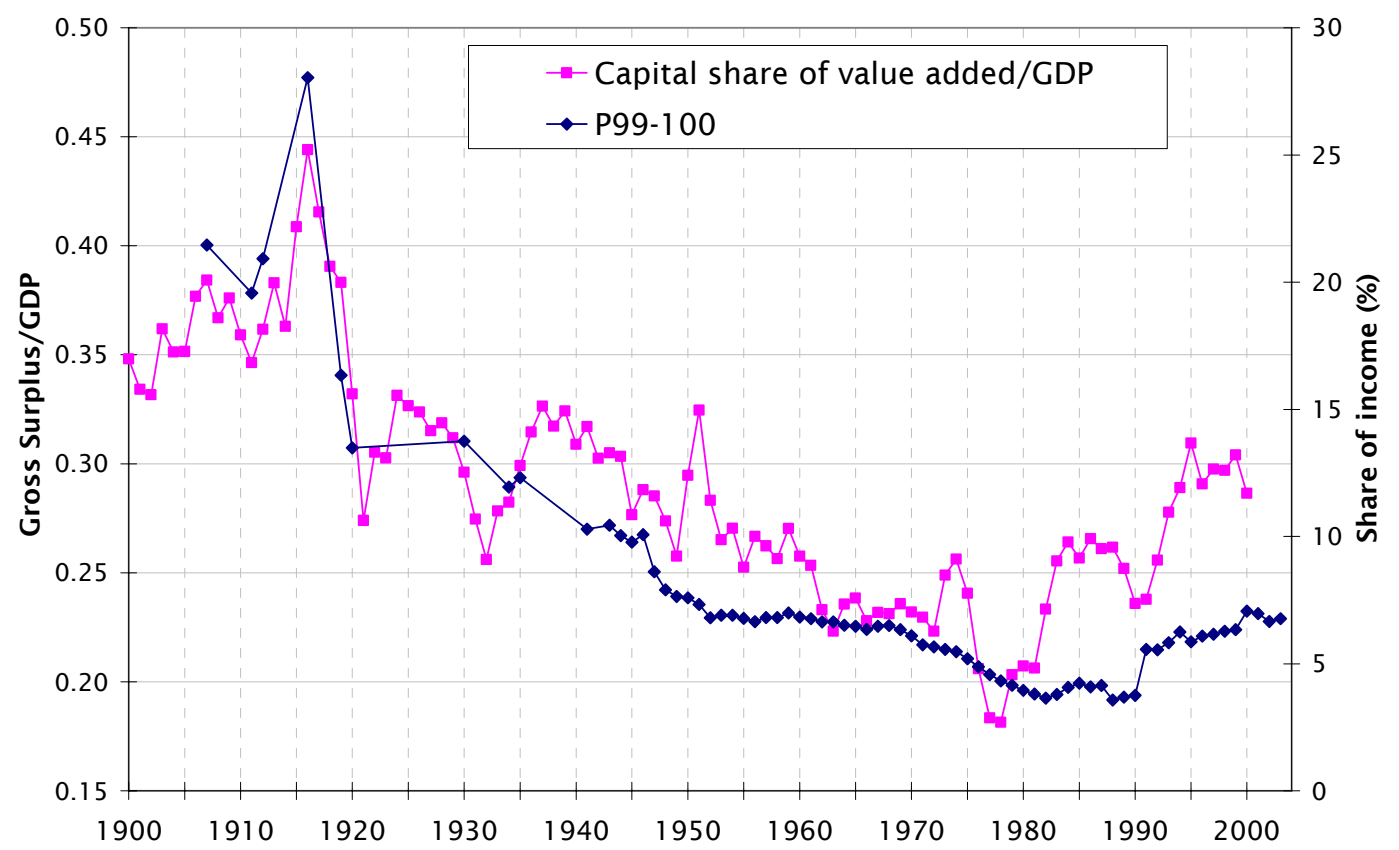

Sources: Data on the capital share of value added and GDP by activity come from Edvinsson (2005). Top income percentile shares come from Appendix table A2 column 1.

Figure 6: The capital share of value added as a share of GDP and the top 1 percent income share, 1903-2003

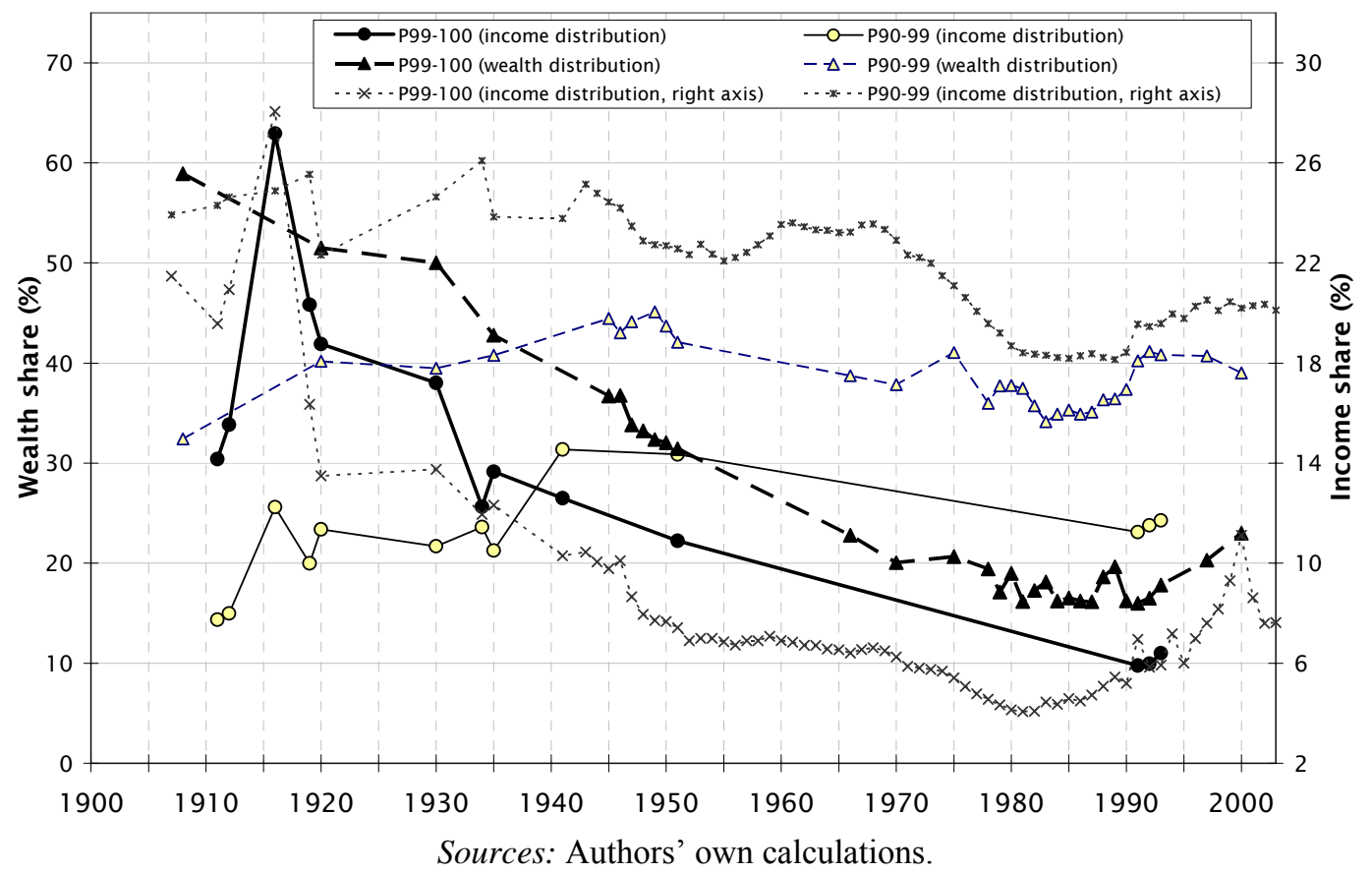

Figure 7: Wealth in Swedish top income and wealth fractiles, 1908-2003. 


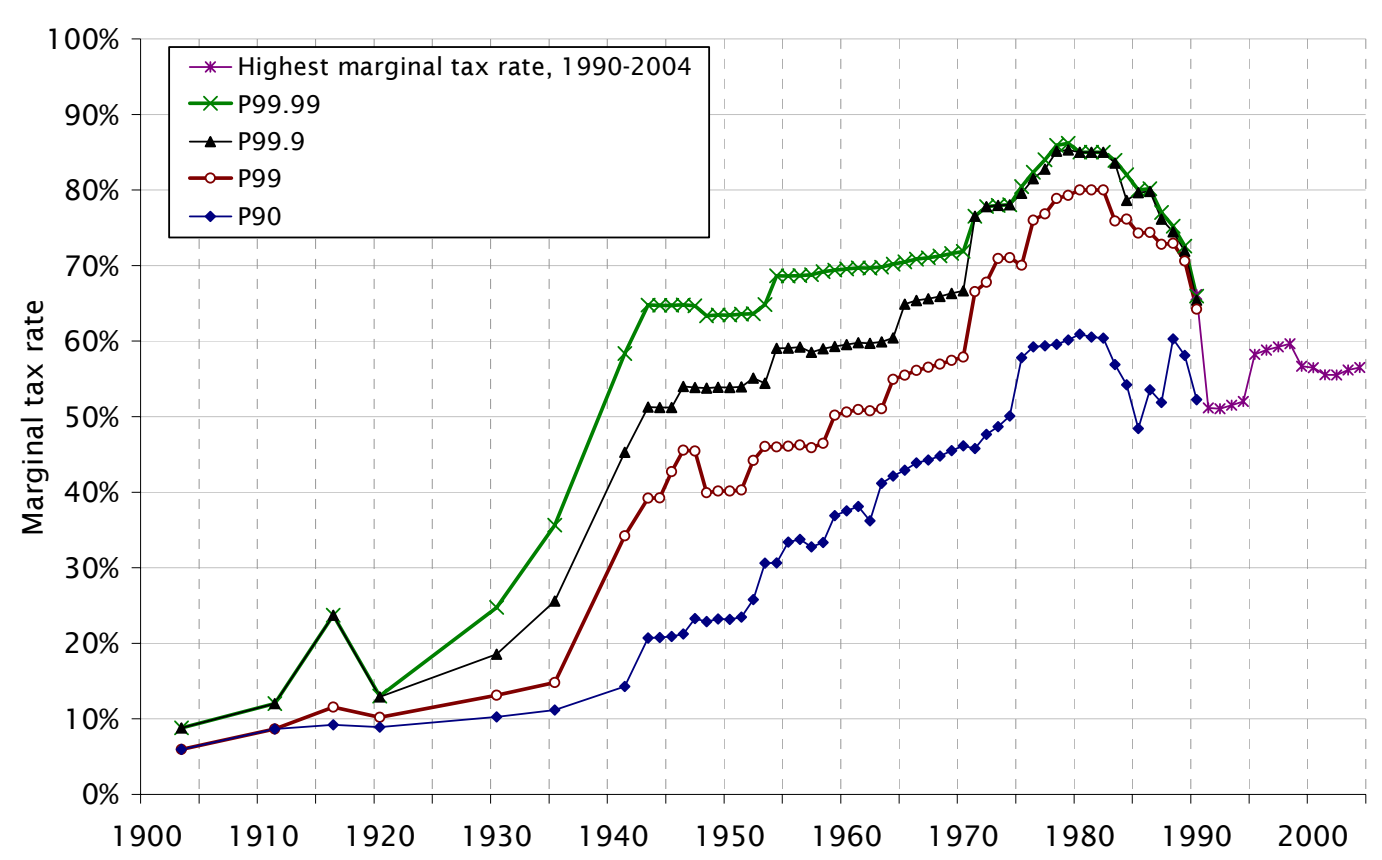

Source: Tax rates are computed for each top income level in Table A4 using tax tables in Söderberg (1996) until 1990. After 1990, we show the "highest marginal tax rate" (Swedish National Tax Board, 2004), applying only to labor income (wages + business income).

Figure 8: Top marginal tax rates in Sweden, 1903-2003

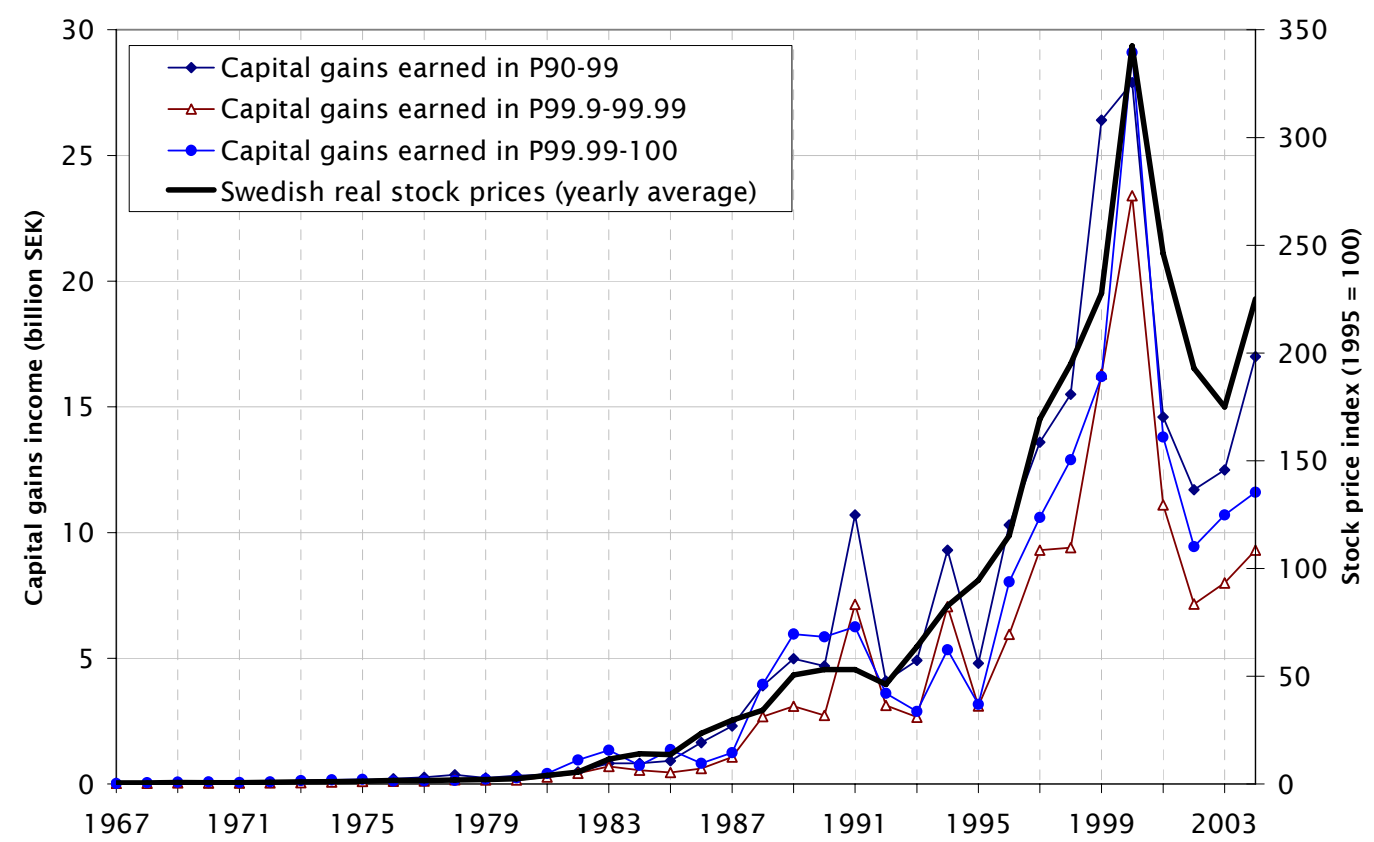

Note: Stock prices are yearly averages of end-of-month prices up to 1979 and daily closing prices thereafter of Affärsvärldens Generalindex (http://www.affarsvarlden.se), deflated with monthly CPI (monthly averages).

Figure 9: Capital gains in some top income fractiles and Swedish real stock prices, 1967-2004 


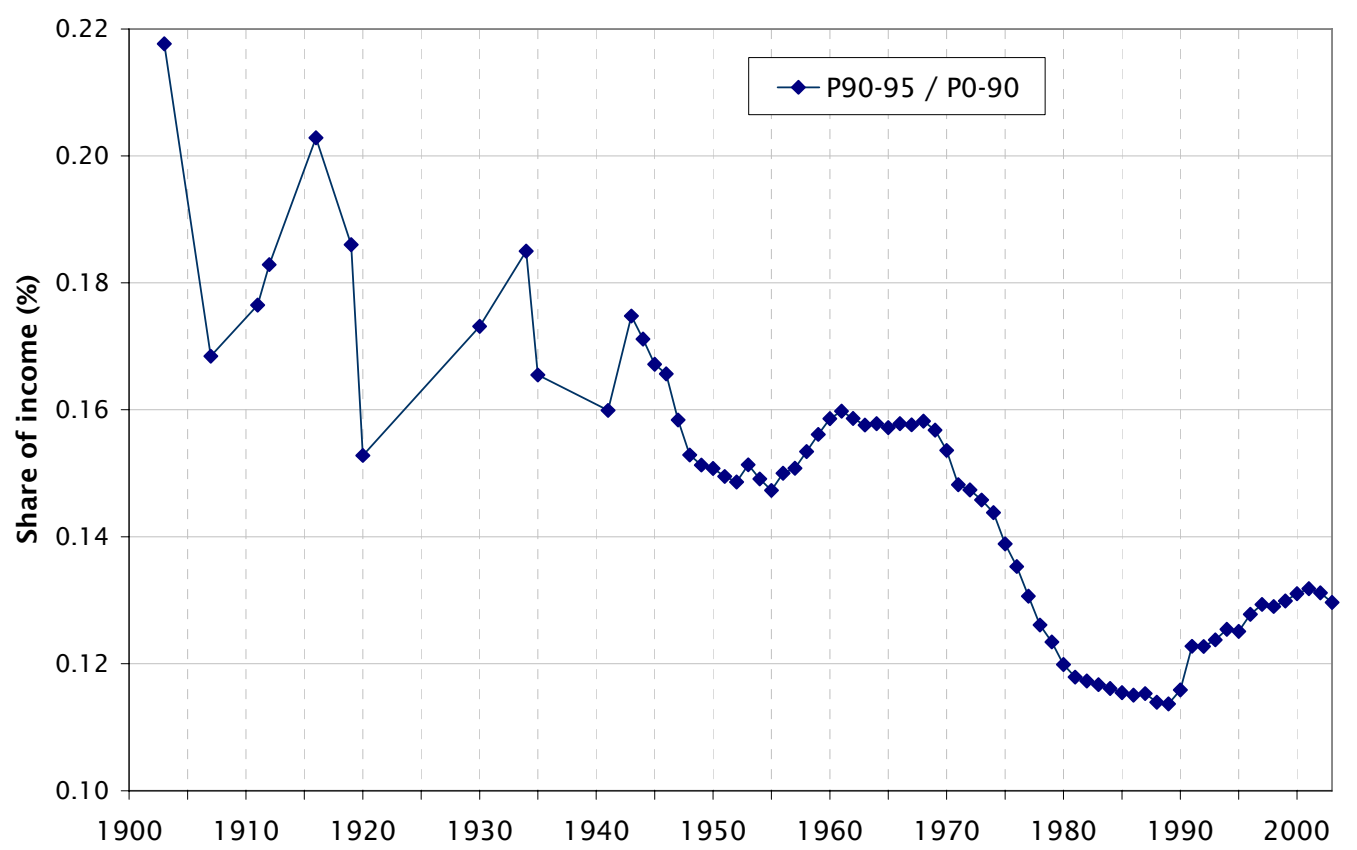

Note: The figure shows the ratio of P90-95 to P0-90 (col. 8 and one minus col. 1 in Table A2).

Figure 10: The Swedish twentieth century "Kuznets curve".

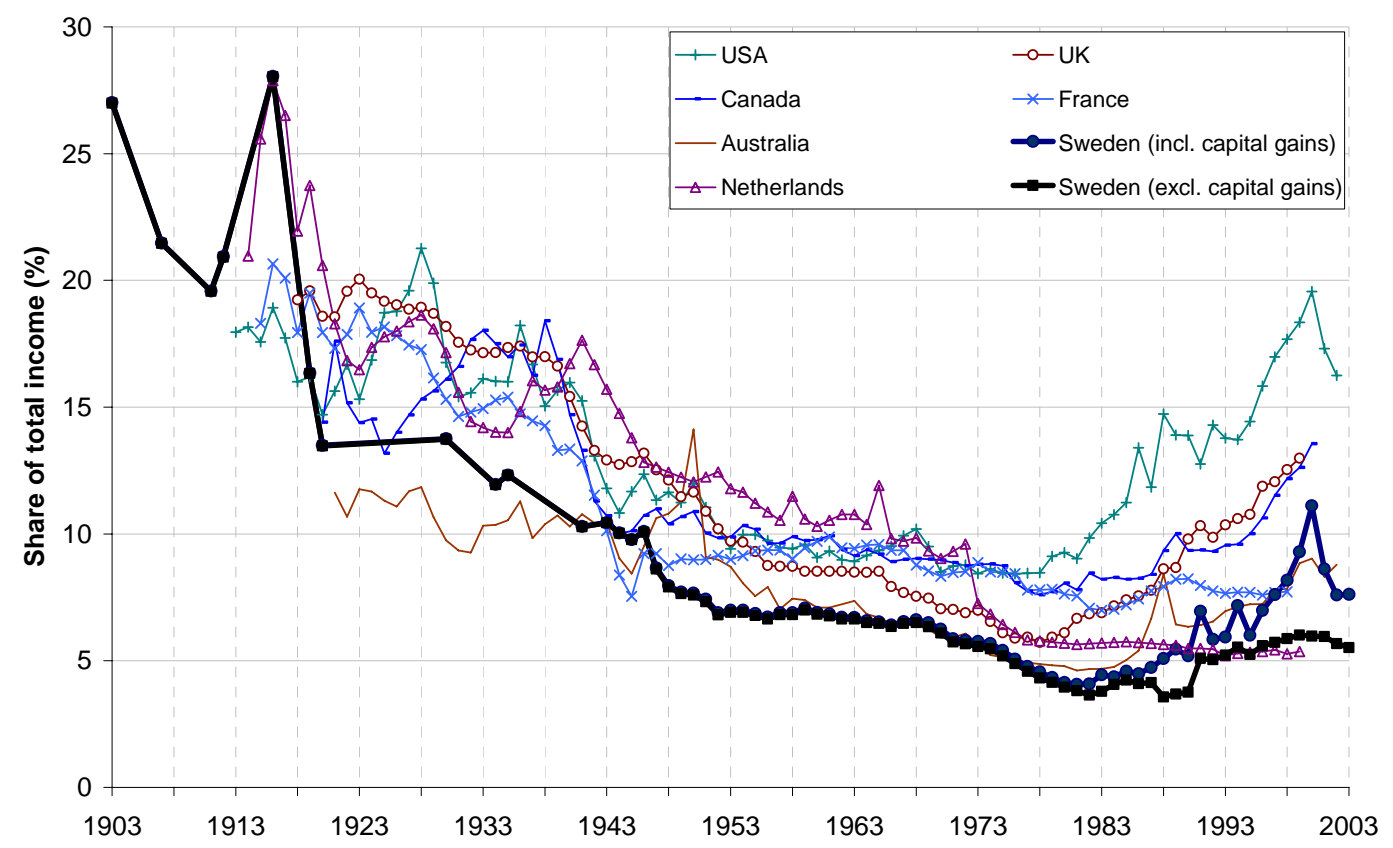

Notes and Sources: Australia (Atkinson and Leigh, 2006), Canada (Saez and Veall, 2005), France (Piketty, 2003), Netherlands and the UK (Atkinson and Salverda, 2005) and the US (Piketty and Saez, 2003).

Figure 11: Income shares of the top percentile in Western countries, 1903-2003. 